\title{
A kingdom in decline: Holocene range contraction of the lion (Panthera leo) modelled with global environmental stratification
}

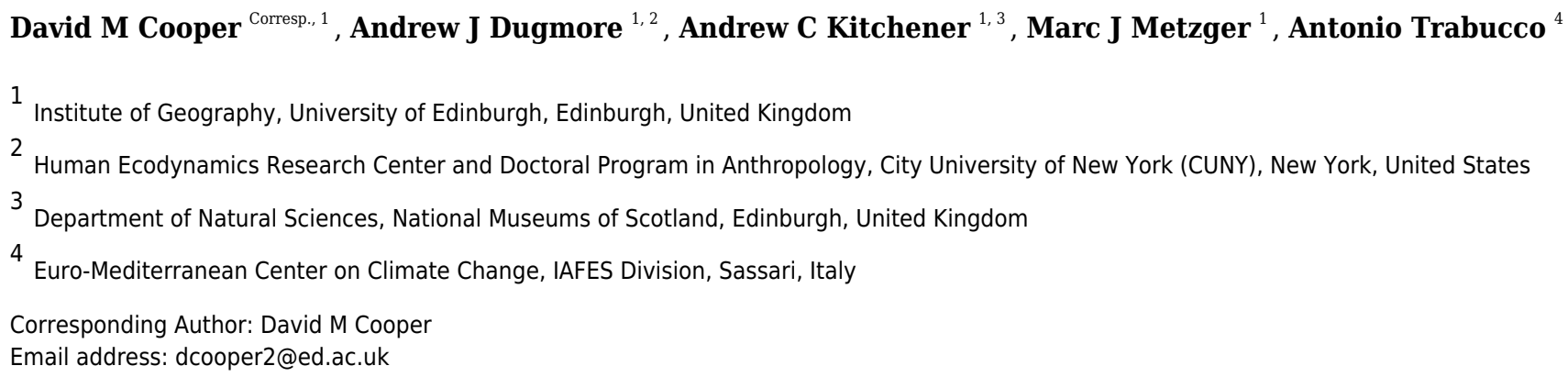

Aim. We use ecological niche models and environmental stratification of palaeoclimate to reconstruct the changing range of the lion (Panthera leo) during the late Pleistocene and Holocene. Location. The modern (early 21st century) range of the lion extends from southern Africa to the western Indian Subcontinent, yet through the 20th century this range has been drastically reduced in extent and become increasingly fragmented as a result of human impacts. Methods. We use Global Environmental Stratification with MaxEnt ecological niche models to map environmental suitability of the lion under current and palaeoclimatic scenarios. By examining modelled lion range in terms of categorical environmental strata, we characterise suitable bioclimatic conditions for the lion in a descriptive manner. Results. We find that lion habitat suitability has reduced throughout the Holocene, controlled by pluvial/interpluvial cycles. The aridification of the Sahara $\sim 6 \mathrm{ka}$ dramatically reduced lion range throughout North Africa. The association of Saharan aridification with the development of pastoralism and the growth of sedentary communities, who practised animal husbandry, would have placed additional and lasting anthropogenic pressures on the lion. Main Conclusions. This research highlights the need to integrate the full effects of the fluctuating vegetation and desiccation of the Sahara into palaeoclimatic models, and provides a starting point for further continentalscale analyses of shifting faunal ranges through North Africa and the Near East during the Holocene. This scale of ecological niche modelling does not explain the pattern of genetic variation in the lion, and we conclude that narrow but substantial physical barriers, such as rivers, have likely played a major role in population vicariance throughout the Late Pleistocene. 
1 A kingdom in decline: Holocene range contraction of the lion (Panthera leo) modelled

2 with Global Environmental Stratification.

3

\section{Authors:}

5 David M. Cooper*1

6 Andrew J. Dugmore ${ }^{1,2}$

7 Andrew C. Kitchener ${ }^{1,3}$

8 Marc J. Metzger ${ }^{1}$

9 Antonio Trabucco 4

10 *ukdavidcooper@gmail.com

$11{ }^{1}$ Institute of Geography, The University of Edinburgh, Drummond Street, Edinburgh, United Kingdom, EH8 9XP

$12{ }^{2}$ Human Ecodynamics Research Center and Doctoral Program in Anthropology, The Graduate Center, City University

13 of New York, 365 5th Ave, New York, NY 10016, USA

$14{ }^{3}$ Department of Natural Sciences, National Museums of Scotland, Chambers Street, EH1 1JF Edinburgh, United

15 Kingdom

${ }^{4}$ Euro-Mediterranean Center on Climate Change, IAFES Division, Via De Nicola 9, 07100 Sassari, Italy

\section{Acknowledgements}

Thanks go to Andreas Soteriades and Jonny Hickie for support in utilising the Random Forests classifier within the Weka software. 
Title

A kingdom in decline. Holocene range contraction of the lion (Panthera leo) modelled with Global Environmental Stratification.

\section{Running title}

Holocene range contraction of the lion.

\section{Abstract}

39

\section{Aim}

We use ecological niche models and environmental stratification of palaeoclimate to reconstruct the changing range of the lion (Panthera leo) during the late Pleistocene and Holocene.

\section{Location}

The modern (early $21^{\text {st }}$ century) range of the lion extends from southern Africa to the western Indian Subcontinent, yet through the $20^{\text {th }}$ century this range has been drastically reduced in extent and become increasingly fragmented as a result of human impacts.

\section{Methods}

We use Global Environmental Stratification with MaxEnt ecological niche models to map environmental suitability of the lion under current and palaeoclimatic scenarios. By examining modelled lion range in terms of categorical environmental strata, we characterise suitable bioclimatic conditions for the lion in a descriptive manner.

\section{Results}

We find that lion habitat suitability has reduced throughout the Holocene, controlled by pluvial/interpluvial cycles. The aridification of the Sahara $\sim 6 \mathrm{ka}$ dramatically reduced lion range throughout North Africa. The association of Saharan aridification with the development of pastoralism and the growth of sedentary communities, who practised animal husbandry, would have placed additional and lasting anthropogenic pressures on the lion.

\section{Main Conclusions}

This research highlights the need to integrate the full effects of the fluctuating vegetation and desiccation of the Sahara into palaeoclimatic models, and provides a starting point for further continental-scale analyses of shifting faunal ranges through North Africa and the Near East during the Holocene. This scale of ecological niche modelling does not explain the pattern of genetic variation in the lion, and we conclude that narrow but substantial physical barriers, such 
64

as rivers, have likely played a major role in population vicariance throughout the Late Pleistocene.

\section{Introduction}

The overall aim of this paper is to model the range changes of the lion (Panthera leo) driven by large-scale climate changes since the Last Glacial Maximum, and evaluate their likely consequences on population distribution and connectivity. This is essential contextualisation for current and continuing anthropogenic impacts on the species. The known historical range of the lion included much of Africa and southeastern Europe; it extended to the Near East, the Arabian Peninsula, and southwest Asia as far as the Indian Subcontinent (Ray, Hunter, \& Zigouris, 2005; A. Schnitzler \& Hermann, 2019; Yamaguchi, Cooper, Werdelin, \& Macdonald, 2004), but today this range is considerably reduced. The lion is an iconic symbol of both Africa and India, but is suffering from rapidly declining numbers and geographical range mostly due to human activities (Bauer, Packer, Funston, Henschel, \& Nowell, 2016). Key threats to the lion in both modern and historic times are habitat reduction, depletion of the wild prey base and direct persecution, which are frequently associated with livestock husbandry and management (Bauer, de longh, \& Sogbohossou, 2010; Black, Fellous, Yamaguchi, \& Roberts, 2013; Inskip \& Zimmermann, 2009). The population and range contraction of the lion is even more pronounced, if the closely related taxa, $P$. (I.) spelaeus (Eurasian cave lion) and $P$. (I.) atrox, (American lion) are included and longer periods of time are considered.

Recent molecular studies recognise a deep genetic division between the 'northern' lions (West Africa, Central Africa and North Africa/Asia), and 'southern' lions (North East Africa, East/Southern Africa and South West Africa) (Barnett et al., 2014; Bertola et al., 2016). Population divergence between the northern and southern groups, recognised as subspecies Panthera leo leo and $P I$. melanochaita respectively, likely emerged since the last interglacial (120-140ka) (Bertola et al., 2016; de Manuel et al., 2020). Similar patterns are proposed for other savanna megafauna in Africa (Bertola et al., 2016; Lorenzen, Heller, \& Siegismund, 2012), suggesting a common environmental driver for genetic and population differentiation.

Whilst there is agreement on evidence for long-term genetic splits across the historical range of the lion, there is considerable variance in the proposed timing of divergence between lion populations as expressed both by the differences between studies, and through the credible confidence intervals stated in each analysis. The proposed causes of long-term genetic differentiation between populations are the bioclimatic conditions associated with pluvial (wetter) and interpluvial (drier) conditions of the Late Pleistocene, which caused widespread changes to preferred habitat, and affected the efficacy of potential geographical boundaries, such as large rivers (Bertola et al., 2016; Lorenzen et al., 2012). Similarly, the wider dispersal of the lion outside Africa has been attributed to changes in climate, with pluvial conditions in northern Africa and the Middle East around 60-47ka (Timmermann \& Friedrich, 2016) being thought to have enabled lion range expansion across Eurasia (Yamaguchi et al., 2004). Whilst lions are 
104 known to cross rivers, increasing water levels of tributaries of the Okavango River/Delta have 105 been shown to affect crossing frequency (Cozzi, Broekhuis, Mcnutt, \& Schmid, 2013), and it is possible that the very large rivers of Africa have provided effective environmental barriers to lion dispersal, especially during the wetter conditions experienced in the Late Pleistocene. Conversely, ribbons of vegetation along river systems may have acted as pathways for dispersal and/or connection through arid areas by providing corridors of favourable habitat for both lions and their prey. However, confidence intervals on genetic divergence times are typically wide (Antunes et al., 2008; Barnett et al., 2014; Bertola et al., 2016), and thus direct correlations between them and known bioclimatic changes lack certainty.

Over geological timescales a species' changing range is a key dimension to interpreting its evolutionary history. It is important to assess the likely drivers of shifting geographical ranges, establish scales, directions and rates of change, and to examine currently fragmented, and recently extirpated populations. Expanding and contracting range shifts may have occurred through climatic and geographical changes, human influences or to changes in species assemblages. The ecological niches of large mammalian carnivores at continental scales are largely dependent on climate (Geffen, Anderson, \& Wayne, 2004; Varela, Lobo, Rodríguez, \& Batra, 2010), which has been used to model the ranges of big cats across Africa and Eurasia (Cooper et al., 2016; Li et al., 2016; Townsend Peterson, Radocy, Hall, Kerbis Peterhans, \& Celesia, 2014). Mammal species are likely to have tracked consistent climatic conditions since the LGM (Martínez-Meyer, Peterson, \& Hargrove, 2004) and palaeoclimatic data are commonly used to infer mammal range shifts from previous glacial conditions to the present (Cooper et al., 2016; Kohli, Fedorov, Waltari, \& Cook, 2014; Li et al., 2016; Rebelo et al., 2012; Varela et al., 2010). The climatic conditions of the Last Glacial Maximum ( 21ka), mid-Holocene ( $6 \mathrm{ka})$ and present day capture the climatic extremes of the Late Pleistocene, and therefore encapsulate the variable degrees of contiguity and vicariance between populations over this period.

Lions have a broad habitat tolerance, with optimal habitat comprising of moist open woodland and thick bush, scrub and grass savanna complexes, yet they are also able to survive in more arid environments (Celesia, Townsend Peterson, Kerbis Peterhans, \& Gnoske, 2010; Eloff, 1973; Nowell \& Jackson, 1996). During the Pleistocene the combined mid-to-low latitude distribution of lions in general was almost ubiquitous except for hyper-arid desert and dense tropical rainforests (Bertola et al., 2016; Nowell \& Jackson, 1996; Yamaguchi et al., 2004), however the extent of favourable habitat has varied through the Quaternary in response to climate change (Nowell \& Jackson, 1996; Riggio et al., 2013). By associating the environmental tolerances of the modern lion with palaeoclimatic data, we can establish the role of a key driver of change. Modelling based on this data can provide likely scenarios for the timeframes of population separation or connection through periods of turbulent climatic conditions, and give critical contextualisation to future threats and conservation management of this Vulnerable IUCN Red List species (Bauer et al., 2016).

142 In this paper we use modelling to explicitly address previous biogeographical speculation of 143 population connectivity and dispersal driven by climate change. We assess likely scales of climate-driven changes by modelling suitable lion habitat for key periods that exhibit the extremes of bioclimatic conditions within the Late Pleistocene and Holocene (Chevalier, Brewer, 
146

147

148

149

150

151

152

153

154

155

156

157

158

159

160

161

162

163

164

165

166

167

168

169

170

171

172

173

174

175

176

177

178

179

180

181

182

183

184

\& Chase, 2017). We thereby constrain our understanding of shifting lion ranges and lion population contiguity through this period within clearly defined limits. We assume that the environmental niche of the lion has been stable. The flexible social structure and ecological niche of the lion is influenced by prey preferences and availability, and resource selection (Bauer, de longh, \& Di Silvestre, 2003; Meena, 2009). Fundamental changes to lion social structure, beyond the limits of present-day populations, are unlikely to have occurred over the time periods modelled within this study (Yamaguchi et al., 2004), giving us additional confidence in our niche modelling approach. Within Africa, we do not consider the role of any extant species in competitively excluding the lion from any otherwise bioclimatically suitable area (see Comley et al., 2020), and no other large African mammalian carnivore has become extinct during the Late Pleistocene or Holocene (Faith, 2014). We limit our analysis to modern lions, and exclude consideration of the extinct Eurasian cave lion because phylogenetic analysis shows that it diverged from modern lions $\sim 500 \mathrm{ka}$ and the two lineages likely did not hybridise following their divergence (de Manuel et al., 2020)

This paper provides a new deep-time perspective on the current deteriorating state of lion populations. This is important for understanding the historical context of the species' present vulnerability, which could be further exacerbated by future global change.

\section{Methods}

Approach

We use Global Environmental Stratification (Marc J. Metzger et al., 2013) with ecological niche models to map environmental suitability of the lion under current and palaeoclimatic scenarios. A Maximum Entropy (MaxEnt) ecological niche modelling approach is used in conjunction with the production of Global Environmental Stratification Strata/Zones (M. J. Metzger et al., 2013; Marc J. Metzger et al., 2013; Soteriades, Murray-Rust, Trabucco, \& Metzger, 2017) to explore the extent of lion distributions through the Late Pleistocene and Holocene under different climatic scenarios. Interpreting ecological niche modelling projections of novel climates can be challenging due to the complexity of considering the combined effects of multiple continuous input variables. However, outputs from niche model habitat suitability maps are not necessarily intuitive or meaningful to the end user (Baldwin, 2009; Merow, Smith, \& Silander, 2013). By examining modelled lion range in terms of Global Environmental Stratification (GEnS) (Marc J. Metzger et al., 2013), we characterise the bioclimatic niche of the lion in a descriptive manner. The methods described here are presented graphically within figure 1

\section{Data}

Lion locality records were collected from across the known historical range, and from a range of independent sources (table 1), so as to reduce the influence of sampling bias in our data (Fei \& $\mathrm{Yu}, 2016)$. The temporal range of these records captures the climatic conditions experienced by modern lions and allows the inclusion of records from now extinct populations. The recognition 
185

of spatial error in locality data is an important consideration (Raxworthy, Ingram, Rabibisoa, \& Pearson, 2007). The maximum locality error of data used here is $50 \mathrm{~km}$, which is acceptable given a $\sim 20 \mathrm{~km}$ diameter of lion home ranges, and much greater dispersal distance of male lions (Funston, Mills, Richardson, \& van Jaarsveld, 2003).

GEnS describes relatively similar biophysical environments, which are derived through statistical clustering of the principal components of the four bioclimatic variables: Growing Degree-Days on a $0^{\circ} \mathrm{C}$ base (Marc J. Metzger et al., 2013), Temperature Seasonality (Hijmans, Cameron, Parra, Jones, \& Jarvis, 2005), Aridity Index, and Potential Evapotranspiration Seasonality (R.J. Zomer et al., 2007; Robert J. Zomer, Trabucco, Bossio, \& Verchot, 2008). Using the modelling approach of Soteriades et al. (2017), the strata were created on a global scale for present-day conditions, and for the mid-Holocene and the Last Glacial Maximum using coupled General Circulation Models (GCMs). We used a Random Forest classifier developed by (Soteriades et al., 2017) on each GCM to create 125 multivariate strata characterised by similar climatic conditions. This was performed using the data-mining and machine-learning software Weka 3.6.4 (Frank, Hall, \& Witten, 2016) at a five-arc-minute resolution. The strata were further aggregated into 18 easily interpretable, structured bioclimatic zones (Marc J. Metzger et al., 2013) Global Environmental Zones are an established aggregation of Global Environmental Strata, created to provide consistent nomenclature and to support the summarising and reporting of results (Marc J. Metzger et al., 2013). Global Environmental Zones (GEnZ) and Strata (GEnS) have been made available for present-day, mid-Holocene and Last Glacial Maximum conditions at http://hdl.handle.net/10283/3274 (Cooper, Dugmore, Kitchener, Metzger, \& Trabucco, 2019) - see Appendix S1 in Supporting Information.

\section{Ecological Niche Modelling}

We used the four environmental variables of the GEnS classification (Growing Degree-Days on a $0^{\circ} \mathrm{C}$ base, Temperature Seasonality, Aridity Index, and Potential Evapotranspiration Seasonality) in our ecological niche model analysis to represent dominant bioclimatic trends. These four variables show low correlation with each other and determine $99.9 \%$ of the total variation of 36 available bioclimatic variables (Marc J. Metzger et al., 2013). The modelling extent $\left(-19^{\circ} \mathrm{W}, 94^{\circ} \mathrm{E},-36^{\circ} \mathrm{S}, 50^{\circ} \mathrm{N}\right)$ is defined by the area accessible to the lion over historical times.

The MaxEnt modelling approach was applied as outlined in Cooper et al., (2016) to create a habitat suitability model of the lion for the present-day. The model was run to fit a Poisson pointprocess model by displaying raw output under the following settings:

'noremoveduplicatepresencerecords', 'noaddsamplestobackground'. Regularization multipliers of 2 and 100,000 background points were chosen (see Appendix S3 of Supporting Information for full parameters). Model performance was measured using the mean area under the receiver operator curve (AUC) (Phillips \& Dudík, 2008) from k-fold cross-validation and spatially independent cross-validation using the ENMeval package (Muscarella et al., 2014) in R (Team, 2015). Spatially independent cross validation is important given the potential for spatial autocorrelation of our localities. Threshold values of suitable/unsuitable areas were derived from 
226

227

228

229

230

231

232

233

234

235

236

237

238

239

240

241

242

243

244

245

246

247

248

249

250

251

252

253

254

255

256

257

258

259

260

261

262

263

the MaxEnt model for comparison with global environmental strata. A modified lowest-presence threshold (Costa, Nogueira, Machado, \& Colli, 2010) was used to determine a binary output of suitable lion habitat. We allowed an omission error of $10 \%(e=10 \%)$ to determine this threshold, which accounts for a level of uncertainty in the quality of our locality records (Peterson, Papeş, \& Soberón, 2008).

\section{Comparison of Lion Ecological Niche Model with Global Environmental Strata}

Climate stratification has been used in the creation of biological monitoring programmes, including the construction of sampling strategies for species distribution models (M. J. Metzger et al., 2013), but it has seen very limited application to the evaluation of these models or to mapping past faunal ranges (Hickie, 2016). Whilst the use of Global Environmental Stratification to create maps of suitability is visually similar to the underlying raw MaxEnt models, it also permits more in-depth analysis of preferred lion habitat, within a general descriptive framework that can be extended to other species, time periods and geographical locations.

The area of suitable habitat for the lion, dictated by the modelled threshold, was calculated for each environmental stratum and zone, as was the total extent used in modelling. Strata were categorised as highly favoured, favoured, utilised, low use and unsuitable, where modelled threshold of suitable habitat accounts for $80-100 \%$ (highly favoured), $60-80 \%$ (favoured), $40-$ $60 \%$ (utilised), $10-40 \%$ (low use) and $<10 \%$ (unsuitable) of the total modelling extent. These categories were then expressed on the strata for the present-day, mid-Holocene and Last Glacial Maximum scenarios. We display the modal value of suitability for multiple mid-Holocene and LGM models (or values, if two similar suitabilities cause a split agreement, e.g. favourable/highly favourable). If model results have no agreement, or the agreement is split between very different suitabilities, e.g. favourable/unsuitable, the strata were categorised as uncertain (see Appendix S2 in Supporting Information).

Additionally, the area of each Global Environmental Zone within the IUCN Red List's extant lion distribution data was calculated to compare the modelled fundamental niche with the realised niche of current lion range (figure 2). To provide environmental context to Global Environmental Zones and Strata within the modelling extent, the proportion of MODIS land cover classes represented by each Zone and Strata was calculated.

\section{$\underline{\text { Results }}$}

Lion environmental preferences

The quantified climatic preferences of the lion, using a MaxEnt ecological niche model of habitat suitability, are shown in figure 3. The AUC value from model 10 -fold cross validation was 0.923 . The model AUC score from spatially independent cross-validation, using the 'checkerboard2' method (Muscarella et al., 2014), was 0.818. The modified lowest-presence threshold (e=10\%) derived from the MaxEnt model was used to calculate 'highly favoured', 'favoured', 'utilised', 'low 
264

265

266

267

268

269

270

271

272

273

274

275

276

277

278

279

280

281

282

283

284

285

286

287

288

289

290

291

292

293

294

295

296

297

298

299

300

301

302

303

use' and 'unsuitable' Global Environmental Strata and Zones within the modelling extent (figure 4, figure 5). Highly favoured and favoured lion habitats predominantly consist of hot and mesic, hot and dry, extremely hot and xeric, and extremely hot and moist environmental zones (figure 4). The modelled scenarios show a wider present-day habitat tolerance than current known lion distributions derived from IUCN data (Bauer et al., 2016), with some favourability modelled within warm temperate zones (figure 4). Within preferred environmental zones, some strata are low use or unsuitable. We compared each environmental stratum to MODIS (Channan, Collins, \& Emanuel, 2014; Friedl et al., 2010) land cover classes to gain insight into the typical land covers of each stratum (see Appendix S6 in Supporting Information). Today's lions prefer strata which are typified by woody savannas and savannas, rather than barren/sparse cover or more closed forest covers, which can occur within the same broader environmental zones.

\section{Modelled Holocene environmental suitability for the lion}

We projected preferred lion habitat upon modelled Global Environmental Strata for present-day conditions, to the mid-Holocene $\sim 6 \mathrm{ka}$ and Last Glacial Maximum (LGM) $21 \mathrm{ka}$ (figure 6). MidHolocene and LGM outputs were derived from multiple coupled GCMs from the Paleoclimate Modelling Intercomparison Project Phase III (PMIP3) and downscaled at 5-min resolution (see Appendix S4 in Supporting Information). Suitable conditions for the lion have fluctuated considerably since the LGM. Compared with present-day interglacial/interpluvial conditions, the LGM was considerably more favourable for the lion in both overall 'favourable' environmental conditions and connectivity across the historical range. Favourable conditions across models have consistently been reduced for the Indian Subcontinent from the LGM through the midHolocene and into present-day conditions. Figure 7 highlights the reduction of highly favoured, favoured and utilised strata and increases in unsuitable and low-use strata from the LGM to the present. Whilst LGM conditions are more favourable to the lion than modelled mid-Holocene or present-day conditions, the core 'favourable' environment has shifted markedly. During the LGM, the favourable lion habitat is consistently modelled across the Sudanian region with comparatively less favourable conditions than the mid-Holocene and present day in southern Africa. The modelled results show the LGM as the most likely time for dispersal out of Africa to the Near East and Indian Subcontinent, but the extent and quality of the linkage is low. In all timeframes and all modelling scenarios, there is little suitable habitat modelled within the Near East, and modelled suitability in southern Europe has a small geographical range. The Congo basin has progressively become less favourable to the lion since the LGM (figure 8).

\section{Discussion}

The mapping of lion habitat suitability, in terms of Global Environmental Strata, provides an insight into their preferred Global Environmental Zones. Whilst certain environmental zones are more favoured by lions, no zone is modelled as universally suitable for the lion, as both favoured and highly favoured strata are found within environmental zones that include unsuitable and low-use strata. This is probably due to the lions' wide habitat tolerance within 
304 transitional landscapes, but limited tolerance of climatic extremes. We expect lion distributions

305

306

307

308

309

310

311

312

313

314

315

316

317

318

319

320

321

322

323

324

325

326

327

328

329

330

331

332

333

334

335

336

337

338

339

340

341

342

343

344

345

346 within semi-desert, but not true desert (Extremely hot and xeric), and in tropical forest, but not dense rainforest (Extremely hot and moist). The non-linear nature of vegetation cover through climatic gradients (Scheffer, Hirota, Holmgren, Van Nes, \& Chapin, 2012) has likely also played a role in the complex suitability of each environmental zone, as highlighted in the association between environmental strata and MODIS landcover (see Appendix S6).

Our modelling of the LGM shows some limited climatic suitability for lion dispersal between Africa and the Indian Subcontinent. This potential is most pronounced south of the present-day An Nafud desert, through the northern Persian Gulf, and eastward through the southern Zagros Mountains and Balochistan. This corridor is characterised by warm temperate and xeric, warm temperate and mesic, and hot and dry environmental zones, and strong environmental gradients across the strata (figure 7). It has been assumed that the lion moved out of Africa via the Sinai Peninsula (Barnett et al., 2014), but the potential dispersal of Hamadryas baboons, Papio hamadryas, to Arabia via the Bab-el-Mandab during the Late Pleistocene (Kopp et al., 2014), when sea levels were lower, raises the possibility that this route was also used by the lion. Whilst lions may have crossed the narrow strait to small areas of favourable habitat, our analysis indicates a parallel and better supported dispersal could have occurred from the Sinai Peninsula into the Arabian Peninsula. Whilst arid conditions persisted within parts of the Sahara (Adkins, DeMenocal, \& Eshel, 2006), the more favourable conditions modelled for the lion within the Sahara/Near East during the LGM is consistent with widespread palaeoenvironmental records showing wetter conditions during this period (Drake, Blench, Armitage, Bristow, \& White, 2011; Jennings et al., 2015; Larrasoaña, Roberts, \& Rohling, 2013; Migliore et al., 2013).

The underlying GEnS/Z datasets we have created suggest that whilst increased vegetation may have penetrated desert zones up to $500 \mathrm{~km}$ northwards of today's southern limits, (as reported by Willis et al., (2013)), inhospitable, hot and arid, and extremely hot and arid climates persisted through much of the Sahara during the mid-Holocene (figure 9). Crucially, however, this persistence of hot and arid conditions is not consistent with a wide body of evidence suggesting that large parts of the Sahara were characterised by well-connected (mega) lakes, rivers and inland deltas during the African Humid Period 11-4ka (Drake et al., 2011; Hoelzmann et al., 1998; Migliore et al., 2013; Tierney, Pausata, \& DeMenocal, 2017; Willis, Bennett, Burrough, Macias-Fauria, \& Tovar, 2013), and populated by a diverse assemblage of present-day subSaharan megafauna (Yeakel et al., 2014). In the absence of a comprehensive fossil record, we include the locations of African rock art which depict lions and other large megafauna, from within the African Humid Period 11-5ka (figure 6, see Appendix S5 in Supporting Information for references). This supports a wider distribution of lions than suggested through our modelling. There is a strong argument that during the 'Green Sahara' episode, the Arabian Peninsula through to the western Indian Subcontinent also experienced wetter conditions, as these were affected by the same monsoonal forcing (Hoelzmann et al., 1998; Jennings et al., 2015; Jones et al., 2013). The disparity between GEnS/Z datasets and other palaeoenvironmental evidence exists because of the short-comings of the underlying palaeoclimatic data within the SaharoArabian Region which has driven our models. The PMIP3 experiments, which drive the WorldClim bioclimatic datasets in our models, do not reproduce the Green Sahara, because several driving mechanisms may not be accounted for in GCMs such as changes in desert 
347

348

349

350

351

352

353

354

355

356

357

358

359

360

361

362

363

364

365

366

367

368

369

370

371

372

373

374

375

376

377

378

379

380

381

382

383

384

385

386

387

388

dust, orbital changes and northward translation of the ITCZ, and vegetation feedbacks are either weak or non-existent (Tierney et al., 2017). As a result, our model is likely to have only captured a minimum distribution of lions within the Sahara during the mid-Holocene. In reality it is likely that during African Humid Period suitable lion habitat was far more extensive across the Sahara and Arabia, and probably southwest Asia as well, thereby providing stronger opportunities for dispersal and connections between populations. Individual lions are highly mobile, with individual males known to disperse $>200 \mathrm{~km}$ within 1-2 years (Funston et al., 2003; van Hooft, Keet, Brebner, \& Bastos, 2018), and even fleeting favourable conditions would have created opportunities for genetic flow. Given the overall weight of evidence, it is likely that during the African Humid Period a series of connected rivers, lakes and deltas existed across the Sahara (Drake et al., 2011) . The ecological changes related to this altered hydrology would have either facilitated the movement of lions across the region by creating both extensive savanna and favourable lakeshore and riparian habitat corridors, or constrained their dispersal by creating water barriers to movement. Thus, the recognition (and confirmation) of a 'Green Sahara' has significant implications for a more detailed understanding of long-term variations of lion population size, and patterns of dispersal within and out of North Africa and the Near East.

There is good evidence for the presence of lions within the Near East and southeastern Europe into historical times (Bartosiewicz, 2009; A. E. Schnitzler, 2011), yet our modelling shows that today these regions have a particularly poor climatic suitability for lions (figure 6, figure 10). One explanation for this could be lion survival in inter-pluvial refugia formed around river systems and water points, and the endurance of relict populations from a previous contiguous range (Black et al., 2013). These limited climatic refugia would have made lion populations particularly vulnerable to anthropogenic pressures within the region, leading to their local extirpation within historical times.

We argue that recent historical populations in the Near East are not an indication of longdistance dispersal routes given the presence of climatic barriers and lack of continuous riparian corridors. About 6000 years ago, the latest phase of aridification across the Sahara and Arabia probably separated lions in India from those in Africa. The Gir population appears to be a relict of more favourable palaeoclimatic conditions, but today there are still significant areas within the Indian Subcontinent which appear to be climatically favourable, such as the Deccan Plateau east of the Western Ghats. Within this eastern range, potential ecological competition with the sympatric tiger, Panthera tigris, may have constrained the lion's potential present-day distribution.

Our modelling indicates that through the pluvial/interpluvial cycles of the Holocene the subSaharan range of lions has always been contiguous, and so we have no evidence for any significant gaps between populations caused by depopulated zones of climatically unfavourable terrestrial habitat. An analysis of nuclear DNA from historical samples of lions (Curry et al. 2020) supports contiguity amongst modern lion populations (but not amongst present-day fragmented populations), but mitochondrial DNA (mtDNA) suggests regional subdivisions. This reflects sexbiased dispersal amongst lions, with males dispersing from natal prides while females remain resident. Sex-biased dispersal implies that something else has created barriers to female lion dispersal between Western African and Eastern/Southern African populations. This is significant 
389

390

391

392

393

394

395

396

397

398

399

400

401

402

403

404

405

406

407

408

409

410

411

412

413

414

415

416

417

418

419

420

421

422

423

424

425

426

427

428

429

430

431

given the pre-Holocene mtDNA divergence amongst these lion populations (Antunes et al., 2008; Barnett et al., 2014; Bertola et al., 2016; de Manuel et al., 2020; Curry et al. 2020), and numerous other large mammalian grassland/savanna species (Bertola et al., 2016). Thus, patterns of regional climate alone are not able to explain longer-term genetic divergence between populations. A combination of less favourable climatic conditions surrounding Lake Turkana within Africa's Rift Valley, and the presence of major physical barriers, such as Lake Turkana itself, other Rift Valley lakes, the Omo River and Nile River systems (figure 11), may have significantly reduced gene flow for large, mobile mammal species such as the lion. Further west, the Niger river system may have substantially reduced gene flow between central and West African populations. The contiguous favourable conditions found in eastern southern Africa throughout the changing climatic conditions of the Late Pleistocene supports the argument for this region as the evolutionary cradle of the modern lion (Barnett et al., 2014). Given the identified discrepancies between the coupled General Circulation Models and climatic proxy data in the northern hemisphere, it is possible that model inconsistencies exist within other regions of interest. PMIP3 experiments show good agreement with palaeoclimate proxy data for the mid-Holocene within eastern Africa, and this region was likely wetter than is modelled during the LGM, whilst south Eastern Africa was likely drier and cooler (Barker \& Gasse, 2003; Chevalier et al., 2017), with African rift lake levels similar to those found today (Barker \& Gasse, 2003). However, the impact of these differences during the LGM is not of the same scale or extent as those found within the Sahara and Arabia during the mid-Holocene. The lowest agreements between PMIP3 models occur towards coastal regions, and differences are not homogenous across East Africa (Singarayer \& Burrough, 2015). However, it is possible that different conditions during the LGM within eastern Africa could have affected lion distributions, and therefore could have contributed to the long-term vicariance of northern and southern populations.

The wetter conditions across North Africa might have effectively counteracted the range reduction in other areas since the LGM and would have allowed lion expansion from southern Africa to northern Africa. However, widespread mixing of populations is not supported by current genetic evidence except in northeast Africa, suggesting climate alone has not constrained lion population differentiation. In recent historical times the centre of gravity of lion distribution has lain in southern or eastern Africa, but in the past, it could have been much further north. Following the desertification of the Sahara, the range changes in the north were proportionally far greater than those in the south, and this may have led to increased genetic drift through population isolation (Yamaguchi et al., 2004). The reduction in suitable habitat for the lion through the Holocene, and especially following the aridification of the Sahara and Arabia has coincided with the development of agricultural systems and rising anthropogenic pressures, creating a double impact on the lion. This modelled range change is consistent with previous skyline plots of lion populations, which show a recent precipitous drop (Bertola et al., 2016). The position of major rivers through Africa, in addition to contractions of suitable habitat driven by climate change, are the likely causes of vicariance over 100ka. Suture zones and parapatric (sub)speciation are likely important in maintaining genetic variation (Bertola et al., 2016; Curry et al., 2020; Curry, White, \& Derr, 2019; Dures, Carbone, Savolainen, Maude, \& Gottelli, 2020). The persistence of major river barriers/corridors in the region, appears to have major 
432 biogeographical legacies in terms of defining boundaries between populations and linkage 433 between areas.

434

The long-term trend in lion range reduction from the LGM into present-day conditions as revealed by our modelling becomes even more pronounced if we consider the possible extent of more benign conditions across the Sahara and Arabia during the African Humid Period and the subsequent persistence of hyper-arid conditions through the region after $\sim 4$.3ka (Kröpelin et al., 2008). A rapid decline in overall lion numbers, as a result of mid-Holocene range contractions driven by climate change, is compatible with a population skyline plot derived from genetic analysis (Bertola et al., 2016). Although the ranges of lions south of the Sahara remained contiguous, climatic change may have led to poor connectivity amongst West African, North African, and European/Asian lion populations. In addition to climate change, the Holocene has witnessed increasing human impacts on lions because humans and lions flourish in the same areas (Kuper \& Kröpelin, 2006), and ultimately competition for favoured habitats has driven the anthropogenic pressure on lions today. Conflicts are likely to have arisen alongside domestication and the development of pastoralism as lions would prove a significant threat as predators of cattle and other livestock (Woodroffe, 2000). Short-lived aridification of the Sahara $\sim 8 \mathrm{ka}$ is associated with widespread transition to pastoralism from hunter-gathering (Dunne et al., 2012; Tierney et al., 2017). With increased aridification, human populations congregated with their domestic livestock within the same ecological refuges as lions (Kuper \& Kröpelin, 2006), thus exacerbating direct conflict between people and lions that probably drove the local extinctions of lions, and created new barriers to lion dispersal and gene flow.

We conclude that there has been a long-term reduction of lion numbers during the Holocene, driven by the coincidental and combined influence of climate change and human impacts. The significant and continuing reduction in lion numbers during the $20^{\text {th }} / 21^{\text {st }}$ centuries (Bauer et al., 2016; Black et al., 2013) is occurring in the context of a global population under increasing pressure. A mutually reinforcing effect of range reductions driven by climate and an intensification of human predation, as found during the last $\sim 6 \mathrm{ka}$, is likely to further intensify in the future.

\section{Core findings}

I. Global Environmental Stratification provides a modelling framework that facilitates descriptive interrogation of our findings.

II. The presence of a Green Sahara is not apparent in the Environmental Zones/Strata, as expected due to the shortfalls of PMIP3 simulations, and this limits our understanding of lion distributions in North Africa during the mid-Holocene.

III. Modelling does not identify any significant areas of favourable habitat for lions extending across the Zagros mountains or the Tigris-Euphrates river basin. As a result, we cannot identify any obvious climatic explanation for lion expansion out of Africa; although this is likely explained by poor model performance within North Africa and the Near East during the mid-Holocene.

IV. Modelling indicates that lion ranges south of the Sahara have been contiguous, so climatic drivers are not responsible for long-term vicariance in lion populations, which 
473

474

475

476

477

478

479

480

481

482

483

484

485

486

487

488

489

490

491

492

493

494

495

496

497

498

499

500

501

502

503

504

505

506

could instead be the result of the discrete geographical barriers formed by rivers, lakes, mountains, etc.

V. There has been a general reduction in lion range from the LGM, through the midHolocene to the present-day.

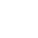

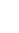

(2)

2

(1)

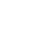

\section{References}

Adkins, J., DeMenocal, P., \& Eshel, G. (2006). The "African humid period" and the record of marine upwelling from excess 230Th in Ocean Drilling Program Hole 658C. Paleoceanography, 21, 1-14. https://doi.org/10.1029/2005PA001200

Antunes, A., Troyer, J. L., Roelke, M. E., Pecon-Slattery, J., Packer, C., Winterbach, C., ... Johnson, W. E. (2008). The evolutionary dynamics of the lion Panthera leo revealed by host and viral population genomics. PLoS Genetics, 4(11), 1-11. https://doi.org/10.1371/journal.pgen.1000251

Baldwin, R. a. (2009). Use of Maximum Entropy Modeling in Wildlife Research. Entropy, 11(4), 854-866. https://doi.org/10.3390/e11040854

Banerjee, K., \& Jhala, Y. V. (2012). Demographic parameters of endangered Asiatic lions (Panthera leo persica) in Gir Forests, India. Journal of Mammalogy, 93(6), 1420-1430. https://doi.org/10.1644/11-MAMM-A-231.1

Barker, P., \& Gasse, F. (2003). New evidence for a reduced water balance in East Africa during the Last Glacial Maximum: Implication for model-data comparison. Quaternary Science Reviews, 22(8-9), 823-837. https://doi.org/10.1016/S0277-3791(03)00010-6

Barnett, R., Yamaguchi, N., Shapiro, B., Ho, S. Y. W., Barnes, I., Sabin, R., ... Larson, G. (2014). Revealing the maternal demographic history of Panthera leo using ancient DNA and a spatially explicit genealogical analysis. BMC Evolutionary Biology, 14(1), 70. https://doi.org/10.1186/1471-2148-14-70 
507

508

509

510

511

512

513

514

515

516

517

518

519

520

521

522

523

524

525

526

527

528

529

530

531

532

533

534

535

536

537

538

539

540

541

542

543

544

545

546

Bartosiewicz, L. (2009). A lion's share of attention: archaeozoology and the historical record. Acta Archaeologica, 60(1), 275-289. https://doi.org/10.1556/AArch.59.2008.2.28

Bauer, H., de longh, H. H., \& Di Silvestre, I. (2003). Lion (Panthera leo) social behaviour in the West and Central African savannah belt. Mammalian Biology, 68(1), 239-243.

Bauer, H., de longh, H., \& Sogbohossou, E. (2010). Assessment and mitigation of human-lion conflict in West and Central Africa. Mammalia, 74(4), 363-367. https://doi.org/10.1515/MAMM.2010.048

Bauer, H., Packer, C., Funston, P. F., Henschel, P., \& Nowell, K. (2016). Panthera leo. Retrieved August 11, 2017, from http://www.iucnredlist.org/details/summary/15951/0

Bertola, L. D., Jongbloed, H., van der Gaag, K. J., de Knijff, P., Yamaguchi, N., Hooghiemstra, H., ... de longh, H. H. (2016). Phylogeographic Patterns in Africa and High Resolution Delineation of Genetic Clades in the Lion (Panthera leo). Scientific Reports, 6(30807), 111. https://doi.org/10.1038/srep30807

Black, S. A., Fellous, A., Yamaguchi, N., \& Roberts, D. L. (2013). Examining the Extinction of the Barbary Lion and Its Implications for Felid Conservation. PLoS ONE, 8(4), 1-12. https://doi.org/10.1371/journal.pone.0060174

Celesia, G. G., Townsend Peterson, a., Kerbis Peterhans, J. C., \& Gnoske, T. P. (2010). Climate and landscape correlates of African lion (Panthera leo) demography. African Journal of Ecology, 48, 58-71. https://doi.org/10.1111/j.1365-2028.2009.01082.x

Channan, S., Collins, K., \& Emanuel, W. R. (2014). Global mosaics of the standard MODIS land cover type data. College Park, Maryland, USA: University of Maryland and the Pacific Northwest National Laboratory.

Chevalier, M., Brewer, S., \& Chase, B. M. (2017). Qualitative assessment of PMIP3 rainfall simulations across the eastern African monsoon domains during the mid-Holocene and the Last Glacial Maximum. Quaternary Science Reviews, 156, 107-120. https://doi.org/10.1016/j.quascirev.2016.11.028

Comley, J., Joubert, C. J., Mgqatsa, N., \& Parker, D. . (2020). Do spotted hyaenas outcompete the big cats in a small, enclosed system in South Africa? Journal of Zoology, 1-9. https://doi.org/10.1111/jzo.12772

Constable, H., Guralnick, R., Wieczorek, J., Spencer, C., \& Peterson, A. T. (2010). VertNet: A new model for biodiversity data sharing. PLoS Biology, 8(2), 1-4. https://doi.org/10.1371/journal.pbio.1000309

Cooper, D. M., Dugmore, A. J., Gittings, B. M., Scharf, A. K., Wilting, A., \& Kitchener, A. C. (2016). Predicted Pleistocene-Holocene range shifts of the tiger (Panthera tigris). Diversity and Distributions, 22(11), 1199-1211. https://doi.org/10.1111/ddi.12484

Cooper, D. M., Dugmore, A. J., Kitchener, A. C., Metzger, M. J., \& Trabucco, A. (2019). Global Environmental Stratification for the mid-Holocene and Last Glacial Maximum, based upon PMIP3 experiments. The University of Edinburgh, School of Geosciences, Institute of Geography. https://doi.org/https://doi.org/10.7488/ds/2509

Costa, G. C., Nogueira, C., Machado, R. B., \& Colli, G. R. (2010). Sampling bias and the use of

PeerJ reviewing PDF | (2020:08:51730:1:0:NEW 29 Oct 2020) 
ecological niche modeling in conservation planning: A field evaluation in a biodiversity hotspot. Biodiversity and Conservation, 19(3), 883-899. https://doi.org/10.1007/s10531009-9746-8

Cozzi, G., Broekhuis, F., Mcnutt, J. W., \& Schmid, B. (2013). Comparison of the effects of artificial and natural barriers on large African carnivores: Implications for interspecific relationships and connectivity. Journal of Animal Ecology, 82(3), 707-715. https://doi.org/10.1111/1365-2656.12039

Cross, P. C., Heisey, D. M., Bowers, J. A., Hay, C. T., Wolhuter, J., Buss, P., ... Getz, W. M. (2009). Disease, predation and demography: Assessing the impacts of bovine tuberculosis on African buffalo by monitoring at individual and population levels. Journal of Applied Ecology, 46(2), 467-475. https://doi.org/10.1111/j.1365-2664.2008.01589.x

Curry, C. J., Davis, B. W., Bertola, L. D., White, P. A., Murphy, W. J., \& Derr, J. N. (2020). Spatiotemporal Genetic Diversity of Lions. BioRxiv Preprint. https://doi.org/10.1101/2020.01.07.896431

Curry, C. J., White, P. A., \& Derr, J. N. (2019). Genetic analysis of African lions (Panthera leo) in Zambia support movement across anthropogenic and geographical barriers. PLOS ONE, 14(5), 1-16. https://doi.org/10.1371/journal.pone.0217179

de Manuel, M., Barnett, R., Sandoval-Velasco, M., Yamaguchi, N., Garrett Vieira, F., Zepeda Mendoza, M. L., ... Gilbert, M. T. P. (2020). The evolutionary history of extinct and living lions. Proceedings of the National Academy of Sciences, 117(20), 201919423. https://doi.org/10.1073/pnas.1919423117

Drake, N. A., Blench, R. M., Armitage, S. J., Bristow, C. S., \& White, K. H. (2011). Ancient watercourses and biogeography of the Sahara explain the peopling of the desert. Proceedings of the National Academy of Sciences, 108(2), 458-462. https://doi.org/10.1073/pnas.1012231108

Dunne, J., Evershed, R. P., Salque, M., Cramp, L., Bruni, S., Ryan, K., ... di Lernia, S. (2012). First dairying in green Saharan Africa in the fifth millennium BC. Nature, 486(7403), 390394. https://doi.org/10.1038/nature11186

Dures, S. G., Carbone, C., Savolainen, V., Maude, G., \& Gottelli, D. (2020). Ecology rather than people restrict gene flow in Okavango-Kalahari lions. Animal Conservation, 1-14. https://doi.org/10.1111/acv.12562

Eloff, F. C. (1973). Water use by the Kalahari Lion Panthera leo vernayi. Koedoe, 16, 149-154.

Faith, J. T. (2014). Late Pleistocene and Holocene mammal extinctions on continental Africa. Earth-Science Reviews, 128, 105-121. https://doi.org/10.1016/j.earscirev.2013.10.009

Fei, S., \& Yu, F. (2016). Quality of presence data determines species distribution model performance: a novel index to evaluate data quality. Landscape Ecology, 31(1), 31-42. https://doi.org/10.1007/s10980-015-0272-7

Frank, E., Hall, M. A., \& Witten, I. H. (2016). The WEKA Workbench. Online Appendix for "Data Mining: Practical Machine Learning Tools and Techniques." (M. Kaufmann, Ed.) (4th ed.).

Friedl, M. A., Sulla-Menashe, D., Tan, B., Schneider, A., Ramankutty, N., Sibley, A., \& Huang, 
X. (2010). MODIS Collection 5 global land cover: Algorithm refinements and characterization of new datasets. Remote Sensing of Environment, 114(1), 168-182. https://doi.org/10.1016/j.rse.2009.08.016

Funston, P. J., Mills, M. G. L., Richardson, P. R. K., \& van Jaarsveld, A. S. (2003). Reduced dispersal and opportunistic territory acquisition in male lions (Panthera leo). Journal of Zoology, 259(2), 131-142. https://doi.org/10.1017/S0952836902003126

Galvin, E. (2018). The British Museum, African Rock Art Image Project. Retrieved July 31, 2018, from https://africanrockart.britishmuseum.org/

Geffen, E., Anderson, M. J., \& Wayne, R. K. (2004). Climate and habitat barriers to dispersal in the highly mobile grey wolf. Molecular Ecology, 13(8), 2481-2490. https://doi.org/10.1111/j.1365-294X.2004.02244.x

Hickie, J. L. D. (2016). Environmental stratification to model shifts in the historic distribution of the giant panda (Ailuropoda melanoleuca) (Masters dissertation). Https://Www.Era.Lib.Ed.Ac.Uk/Handle/1842/19492. Retrieved from https://www.era.lib.ed.ac.uk/handle/1842/19492

Hijmans, R. J., Cameron, S. E., Parra, J. L., Jones, P. G., \& Jarvis, A. (2005). Very high resolution interpolated climate surfaces for global land areas. International Journal of Climatology, 25(15), 1965-1978. https://doi.org/10.1002/joc.1276

Hoelzmann, P., Jolly, D., Harrison, S. P., Laarif, F., Bonnefille, R., \& Pachur, H. . (1998). MidHolocene land-surface conditions in northern Africa and the Arabian peninsula: A data set of the analysis of biogeographical feedbacks in the climate system. Global Biogeochemical Cycles, 12(1), 35-51. Retrieved from http://onlinelibrary.wiley.com/doi/10.1029/97GB02733/full

iNaturalist. (2015). iNaturalist Research-grade Observations. Retrieved May 31, 2018, from iNaturalist.org

Inskip, C., \& Zimmermann, A. (2009). Human-felid conflict: A review of patterns and priorities worldwide. Oryx, 43(1), 18-34. https://doi.org/10.1017/S003060530899030X

Jennings, R. P., Singarayer, J., Stone, E. J., Krebs-Kanzow, U., Khon, V., Nisancioglu, K. H., ... Petraglia, M. D. (2015). The greening of Arabia: Multiple opportunities for human occupation of the Arabian Peninsula during the Late Pleistocene inferred from an ensemble of climate model simulations. Quaternary International, 382(August), 181-199. https://doi.org/10.1016/j.quaint.2015.01.006

Jones, M., Djamali, M., Stevens, L., Heyvaert, V., Askari, H., Noorollahi, D., \& Weeks, L. (2013). Mid-Holocene environmental and climatic change in Iran. In C. A. Petrie (Ed.), Ancient Iran and its Neighbours: Local Developments and Long-range Interactions in the 4th Millenium $B C$. Oxford: Oxbow books.

Kohli, B. A., Fedorov, V. B., Waltari, E., \& Cook, J. A. (2014). Phylogeography of a Holarctic rodent (Myodes rutilus ): testing high-latitude biogeographical hypotheses and the dynamics of range shifts. Journal of Biogeography, n/a-n/a. https://doi.org/10.1111/jbi.12433

Kopp, G. H., Roos, C., Butynski, T. M., Wildman, D. E., Alagaili, A. N., Groeneveld, L. F., \& 
628

629

630

631

632

633

634

635

636

637

638

639

640

641

642

643

644

645

646

647

648

649

650

651

652

653

654

655

656

657

658

659

660

661

662

663

664

665

666

667

668

Zinner, D. (2014). Out of Africa, but how and when? The case of hamadryas baboons (Papio hamadryas). Journal of Human Evolution, 76, 154-164. https://doi.org/10.1016/j.jhevol.2014.08.003

Kröpelin, S., Verschuren, D., Lezine, A.-M., Eggermont, H., Cocquyt, C., Francus, P., ... Engstrom, D. R. (2008). Climate-Driven Ecosystem Succession in the Sahara: The Past 6000 Years. Science, 320, 765-768. https://doi.org/10.1126/science.1163483

Kuper, R., \& Kröpelin, S. (2006). Climate-Controlled Holocene Occupation in the Sahara: Motor of Africa's Evolution. Science, 313(5788), 803-807. https://doi.org/10.1126/science.1130989

Larrasoaña, J. C., Roberts, A. P., \& Rohling, E. J. (2013). Dynamics of Green Sahara Periods and Their Role in Hominin Evolution. PLOS ONE, 8(10). https://doi.org/10.1371/journal.pone.0076514

Li, J., McCarthy, T. M., Wang, H., Weckworth, B. V., Schaller, G. B., Mishra, C., .. Beissinger, S. R. (2016). Climate refugia of snow leopards in High Asia. Biological Conservation, 203, 188-196. https://doi.org/10.1016/j.biocon.2016.09.026

Lorenzen, E. D., Heller, R., \& Siegismund, H. R. (2012). Comparative phylogeography of African savannah ungulates. Molecular Ecology, 21(15), 3656-3670. https://doi.org/10.1111/j.1365-294X.2012.05650.x

Loveridge, A. J., \& Canney, S. (2009). Report to Born Free Foundation on the Lion Distribution and Conservation Modelling Project.

Martínez-Meyer, E., Peterson, A. T., \& Hargrove, W. W. (2004). Ecological niches as stable distributional constraints on mammal species, with implications for Pleistocene extinctions and climate change projections for biodiversity. Global Ecology and Biogeography, 13, 305-314.

Meena, V. (2009). Variation in social organisation of lions with particular reference to the Asiatic Lions Panthera leo persica (Carnivora: Felidae) of the Gir forest, India. Journal of Threatened Taxa, 1(3), 158-165. https://doi.org/10.11609/jott.02095.158-65

Merow, C., Smith, M. J., \& Silander, J. A. (2013). A practical guide to MaxEnt for modeling species' distributions: What it does, and why inputs and settings matter. Ecography, 36(10), 1058-1069. https://doi.org/10.1111/j.1600-0587.2013.07872.x

Metzger, M. J., Brus, D. J., Bunce, R. G. H., Carey, P. D., Gonçalves, J., Honrado, J. P., ... Zomer, R. (2013). Environmental stratifications as the basis for national, European and global ecological monitoring. Ecological Indicators, 33, 26-35. https://doi.org/10.1016/j.ecolind.2012.11.009

Metzger, Marc J., Bunce, R. G. H., Jongman, R. H. G., Sayre, R., Trabucco, A., \& Zomer, R. (2013). A high-resolution bioclimate map of the world: A unifying framework for global biodiversity research and monitoring. Global Ecology and Biogeography, 22(5), 630-638. https://doi.org/10.1111/geb.12022

Migliore, J., Baumel, A., Juin, M., Fady, B., Roig, A., Duong, N., \& Médail, F. (2013). Surviving in Mountain Climate Refugia: New Insights from the Genetic Diversity and Structure of the Relict Shrub Myrtus nivellei (Myrtaceae) in the Sahara Desert. PLoS ONE, 8(9), 1-10. 
669

670

671

672

673

674

675

676

677

678

679

680

681

682

683

684

685

686

687

688

689

690

691

692

693

694

695

696

697

698

699

700

701

702

703

704

705

706

707

708

https://doi.org/10.1371/journal.pone.0073795

Muscarella, R., Galante, P. J., Soley-Guardia, M., Boria, R. A., Kass, J. M., Uriarte, M., \& Anderson, R. P. (2014). ENMeval: An R package for conducting spatially independent evaluations and estimating optimal model complexity for Maxent ecological niche models. Methods in Ecology and Evolution, 5(11), 1198-1205. https://doi.org/10.1111/2041210X.12261

Nowell, K., \& Jackson, P. (1996). The Wildcats: A Status Survey and Conservation Action Plan. Gland, Switzerland: IUCN.

Peterson, A. T., Papeş, M., \& Soberón, J. (2008). Rethinking receiver operating characteristic analysis applications in ecological niche modeling. Ecological Modelling, 213(1), 63-72. https://doi.org/10.1016/j.ecolmodel.2007.11.008

Phillips, S. J., \& Dudík, M. (2008). Modeling of species distributions with Maxent: new extensions and a comprehensive evaluation. Ecography, 31, 161-175. https://doi.org/10.1111/j.2007.0906-7590.05203.x

Raxworthy, C. J., Ingram, C. M., Rabibisoa, N., \& Pearson, R. G. (2007). Applications of ecological niche modeling for species delimitation: a review and empirical evaluation using day geckos (Phelsuma) from Madagascar. Systematic Biology, 56(6), 907-923. https://doi.org/10.1080/10635150701775111

Ray, J. C., Hunter, L. T. B., \& Zigouris, J. (2005). Setting Conservation and Research Priorities for Larger African Carnivores. p.203. Available at: http://www.catsg.org/cheetah/05_. Wildlife Conservation Society, 24, 1-203. https://doi.org/10.1017/s0952836905007508

Rebelo, H., Froufe, E., Brito, J. C., Russo, D., Cistrone, L., Ferrand, N., \& Jones, G. (2012). Postglacial colonization of Europe by the barbastelle bat: agreement between molecular data and past predictive modelling. Molecular Ecology, 21(11), 2761-2774. https://doi.org/10.1111/j.1365-294X.2012.05566.X

Riggio, J., Jacobson, A., Dollar, L., Bauer, H., Becker, M., Dickman, A., ... Pimm, S. (2013). The size of savannah Africa: A lion's (Panthera leo) view. Biodiversity and Conservation, 22(1), 17-35. https://doi.org/10.1007/s10531-012-0381-4

Scheffer, M., Hirota, M., Holmgren, M., Van Nes, E. H., \& Chapin, F. S. (2012). Thresholds for boreal biome transitions. Proceedings of the National Academy of Sciences of the United States of America, 109(52), 21384-21389. https://doi.org/10.1073/pnas.1219844110

Schnitzler, A. E. (2011). Past and present distribution of the North African-Asian lion subgroup: a review. Mammal Review, 41(3), 220-243. https://doi.org/10.1111/j.13652907.2010.00181.x

Schnitzler, A., \& Hermann, L. (2019). Chronological distribution of the tiger Panthera tigris and the Asiatic lion Panthera leo persica in their common range in Asia. Mammal Review, 49, 340-353. https://doi.org/10.1111/mam.12166

Singarayer, J. S., \& Burrough, S. L. (2015). Interhemispheric dynamics of the African rainbelt during the late Quaternary. Quaternary Science Reviews, 124, 48-67. https://doi.org/10.1016/j.quascirev.2015.06.021 
709

710

711

712

713

714

715

716

717

718

719

720

721

722

723

724

725

726

727

728

729

730

731

732

733

734

735

736

737

738

739

740

741

742

743

744

745

746

747

748

Soteriades, A. D., Murray-Rust, D., Trabucco, A., \& Metzger, M. J. (2017). Understanding global climate change scenarios through bioclimate stratification. Environmental Research Letters, 12, 1-10.

Team, R. C. (2015). R: A language and environment for statistical computing. Vienna, Austria. Retrieved from https://www.r-project.org/

Tierney, J. E., Pausata, F. S. R., \& DeMenocal, P. B. (2017). Rainfall regimes of the Green Sahara. Science Advances, 3(1), e1601503. https://doi.org/10.1126/sciadv.1601503

Timmermann, A., \& Friedrich, T. (2016). Late Pleistocene climate drivers of early human migration. Nature, 538(7623), 92-95. https://doi.org/10.1038/nature19365

Townsend Peterson, A., Radocy, T., Hall, E., Kerbis Peterhans, J. C., \& Celesia, G. G. (2014). The potential distribution of the Vulnerable African lion Panthera leo in the face of changing global climate. Oryx, 48(4), 1-10. https://doi.org/10.1017/S0030605312000919

van Hooft, P., Keet, D. F., Brebner, D. K., \& Bastos, A. D. S. (2018). Genetic insights into dispersal distance and disperser fitness of African lions (Panthera leo) from the latitudinal extremes of the Kruger National Park, South Africa. BMC Genetics, 19(1), 1-16. https://doi.org/10.1186/s12863-018-0607-x

Varela, S., Lobo, J. M., Rodríguez, J., \& Batra, P. (2010). Were the Late Pleistocene climatic changes responsible for the disappearance of the European spotted hyena populations? Hindcasting a species geographic distribution across time. Quaternary Science Reviews, 29(17-18), 2027-2035. https://doi.org/10.1016/j.quascirev.2010.04.017

Willis, K. J., Bennett, K. D., Burrough, S. L., Macias-Fauria, M., \& Tovar, C. (2013). Determining the response of African biota to climate change : using the past to model the future. Philosophical Transactions of the Royal Society B, 1-9.

Woodroffe, R. (2000). Predators and people: Using human densities to interpret declines of large carnivores. Animal Conservation, 3(2), 165-173. https://doi.org/10.1017/S136794300000086X

Yamaguchi, N., Cooper, A., Werdelin, L., \& Macdonald, D. W. (2004). Evolution of the mane and group-living in the lion (Panthera leo): A review. Journal of Zoology, 263, 329-342. https://doi.org/10.1017/S0952836904005242

Yeakel, J. D., Pires, M. M., Rudolf, L., Dominy, N. J., Koch, P. L., Guimarães, P. R., \& Gross, T. (2014). Collapse of an ecological network in Ancient Egypt. Proceedings of the National Academy of Sciences of the United States of America, 111(40), 14472-14477. https://doi.org/10.1073/pnas.1408471111

Zomer, R.J., Bossio, D. A., Trabucco, A., Yuanjie, L., Gupta, D. C., \& Singh, V. P. (2007). Trees and Water: Smallholder agroforestry on irrigated lands in Northern India. Columbo, Sri Lanka: International Water Management Institute.

Zomer, Robert J., Trabucco, A., Bossio, D. A., \& Verchot, L. V. (2008). Climate change mitigation: A spatial analysis of global land suitability for clean development mechanism afforestation and reforestation. Agriculture, Ecosystems and Environment, 126(1-2), 6780. https://doi.org/10.1016/j.agee.2008.01.014

Peer) reviewing PDF | (2020:08:51730:1:0:NEW 29 Oct 2020) 
Data Accessibility Statement

751 The datasets generated and analysed during the current study are available in Edinburgh

752 DataShare (http://hdl.handle.net/10283/3274 (Cooper et al., 2019))

753

754

\section{Tables}

755 Table 1: Source and number of locality points used in the ecological niche modelling process, compiled from new 756 data (museum specimen locality descriptions) and from additional literature and resources.

\begin{tabular}{|c|c|}
\hline Locality Source & Number of localities \\
\hline $\begin{array}{l}\text { iNaturalist grade } \\
\text { (iNaturalist, 2015) }\end{array}$ & 781 \\
\hline Loveridge \& Canney, 2009 & 134 \\
\hline Museum Record Descriptions & 101 \\
\hline $\begin{array}{l}\text { VertNet Records (Constable, Guralnick, } \\
\text { Wieczorek, Spencer, \& Peterson, 2010) }\end{array}$ & 32 \\
\hline Black et al., 2013 & 20 \\
\hline Barnett et al., 2014 & 20 \\
\hline Banerjee \& Jhala, 2012 & 12 \\
\hline Cross et al., 2009 & 6 \\
\hline Total & 1135 \\
\hline
\end{tabular}

757

758

759

760

761

762

763

764

765

766 


\section{Figure 1}

Bioclimatic modelling methodology

Bioclimatic variables from the present-day, mid-Holocene and Last Glacial Maximum are clustered into Global Environmental Zones (GEnZ) and Strata (GEnS). The same bioclimatic variables are used in conjunction with lion localities to produce a MaxEnt lion suitability threshold model for the present-day. Global Environmental Strata are then classified by suitability for the lion and displayed for each time period in terms of favourability. This method enables the production of habitat suitability maps within a descriptive bioclimatic framework. 


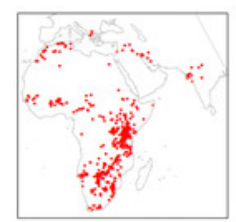

Lion localities

(1135 points)

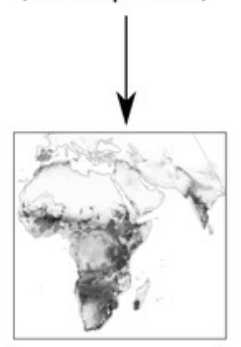

MaxEnt

Lion Suitability

Model

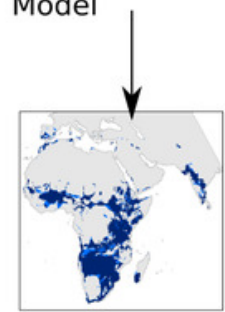

MaxEnt

Lion Suitability

Thresholds

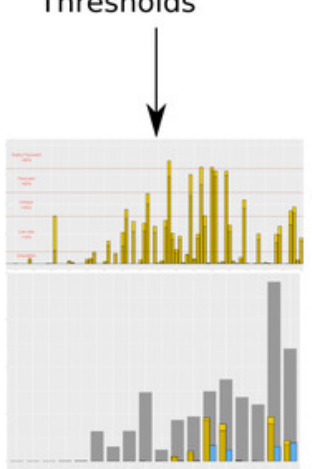

Areas of GEnS/GEnZ

within suitability thresholds

calculated as \% area of modelling extent.

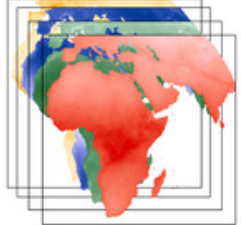

Present Day

Bioclimatic

Variables
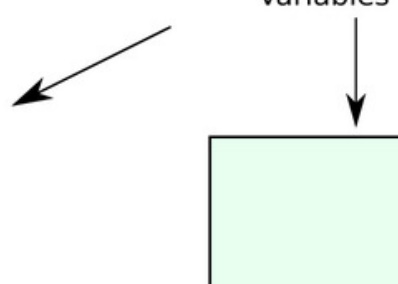

Global Environmental

Zone/Strata creation

using methods of

Soteriades et al., (2017)

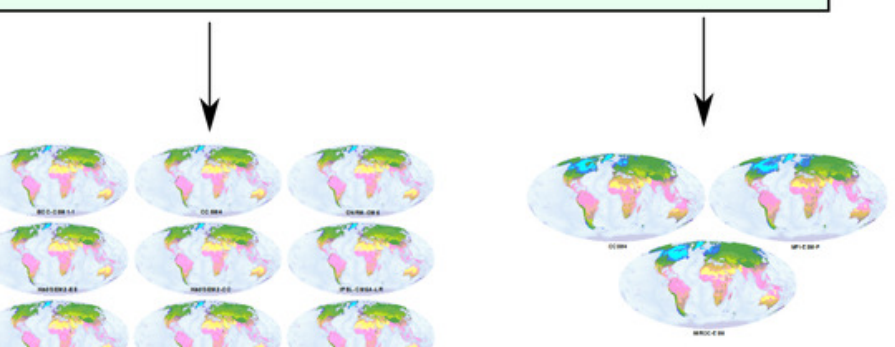

Present Day

GEnZ/GEnS

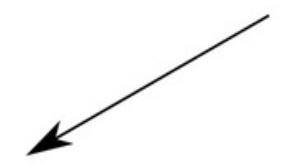

Mid Holocene

GEnZ/GEnS

(3 GCM's)

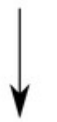

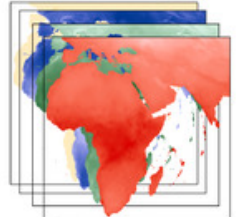

Last Glacial Maximum Bioclimatic

Variables (3 GCM's)
Last Glacial Maximum GEnZ/GEnS

(3 GCM's)

Multiple GCM's reduced to single favourability output for each time period

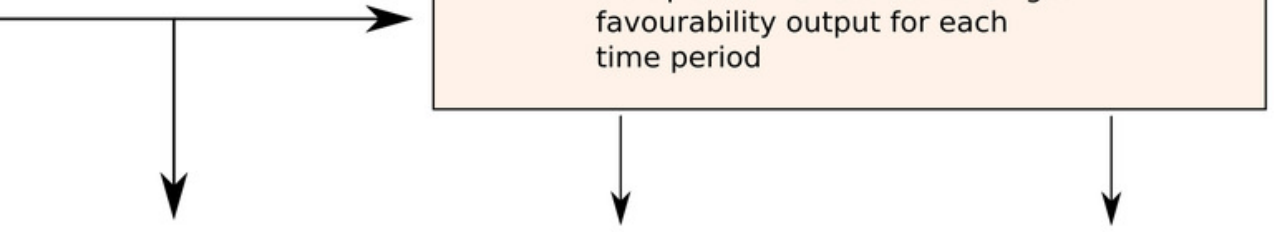

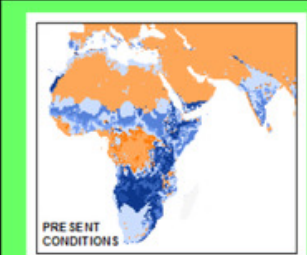

Present

Lion Favorability dictated by GEnS

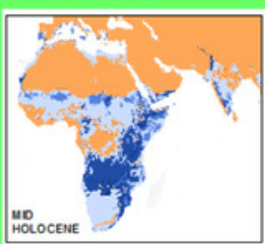

Mid Holocene Lion Favorability dictated by GEnS

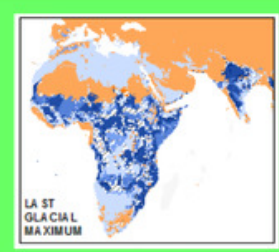

Last Glacial Maximum Lion Favorability dictated by GEnS

MODEL OUTPUT 
Figure 2

Methodology for the comparative assessment of favourable lion range with present-day range, and landcover

Present-day IUCN lion distribution is compared with Global Environmental Zones to visualise the current realised niche of the lion. MODIS Landcover Classes for the present-day are compared with Global Environmental Strata within the modelling extent to provide landcover examples for each stratum.

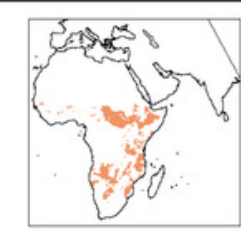

Present Day Lion Distribution IUCN

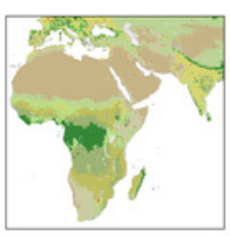

MODIS Landcover Classes, Present Day
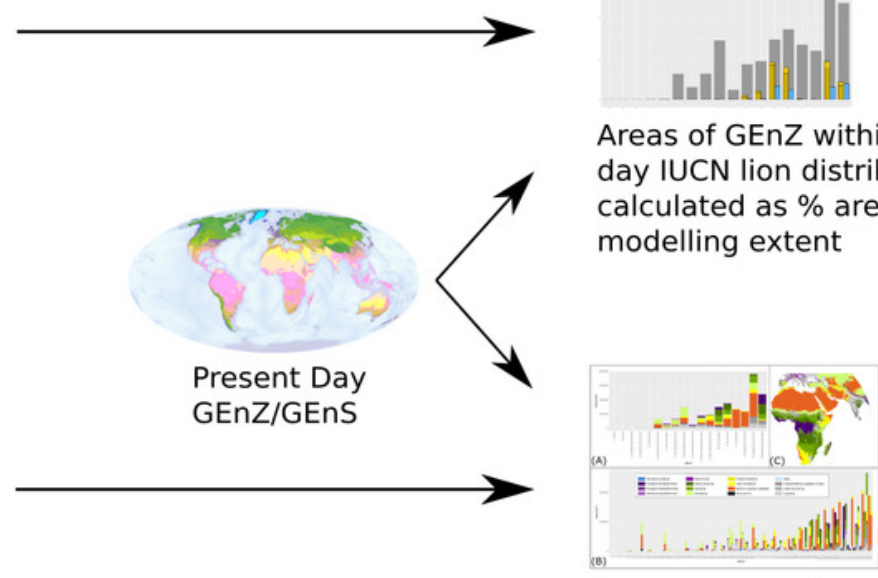

The representation of modis landcover classes within GEnS/Z categories within the modelling extent.
COMPARATIVE ANALYSIS 


\section{Figure 3}

MaxEnt modelling results, genetic demarcations of the modern lion, and potential biogeographical barriers within Africa and the Near East

We highlight the proposed genetic demarcations of the modern lion across Africa, the Near East and southern Asia (Bertola et al., 2016) and the location of large rivers and lakes as potential influencers of lion dispersal that are not accounted for in our models (a). The raw output of our MaxEnt model displays areas climatically favourable to the lion (b). The current known range of the modern lion (orange) is restricted to a subset of modelled favourable habitat. 

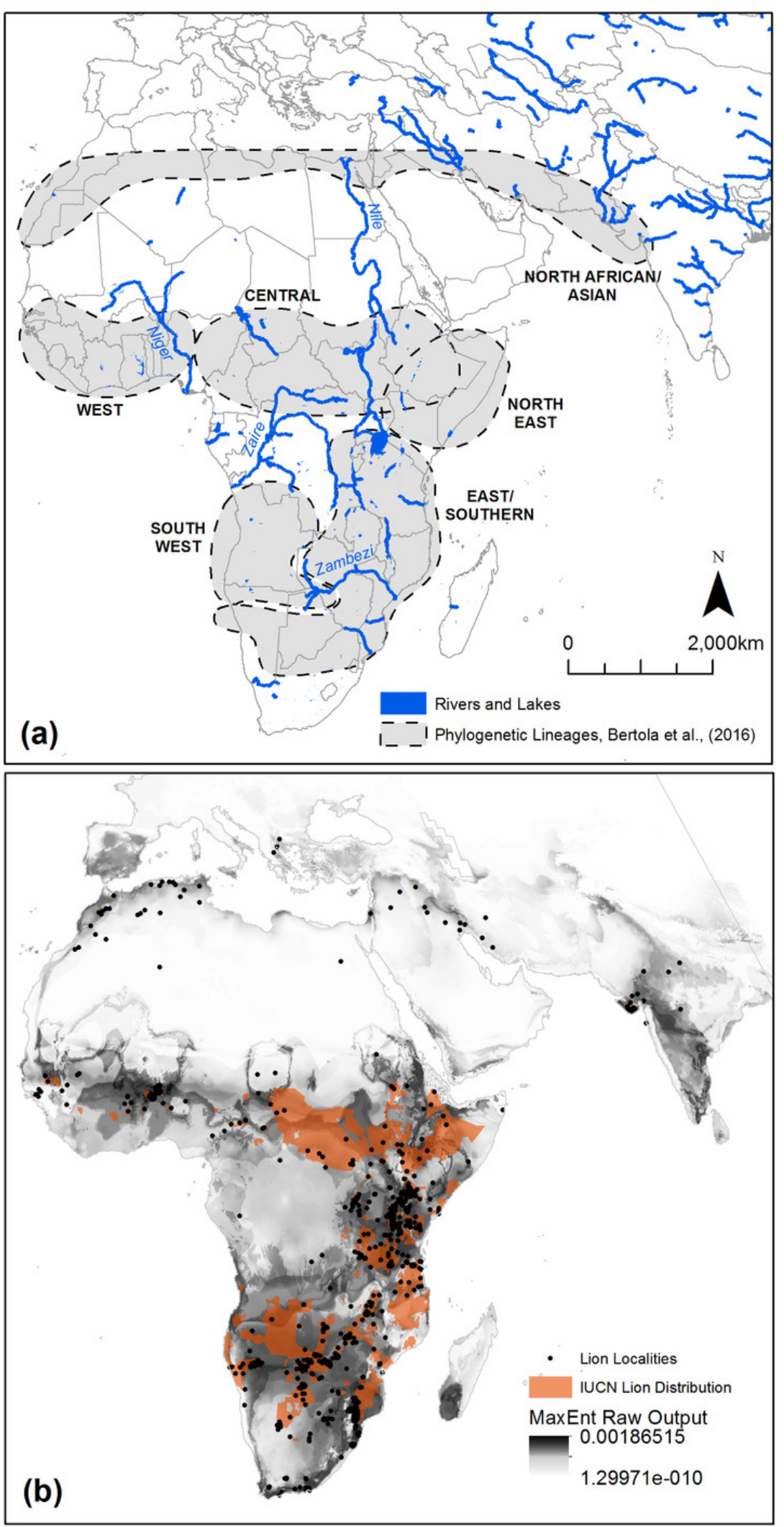


\section{Figure 4}

The proportion of Global Environmental Zones that is occupied by modelled lion distribution based on climatic suitability, and on IUCN extant lion range within our modelling extent.

The proportion of Global Environmental Zones that is occupied by modelled lion distribution based on climatic suitability, and on IUCN extant lion range within our modelling extent of Africa, the Near East, and the Indian Subcontinent. Lions occupy warm temperate and mesic, hot and mesic, hot and dry, extremely hot and xeric, and extremely hot and moist habitat as shown by both modelled results and extant distributions. Hot and mesic, and hot and dry habitats are particularly favoured under idealised model scenarios. Significant reductions in extant range, compared with modelled range, were likely to be caused by anthropogenic pressures. 


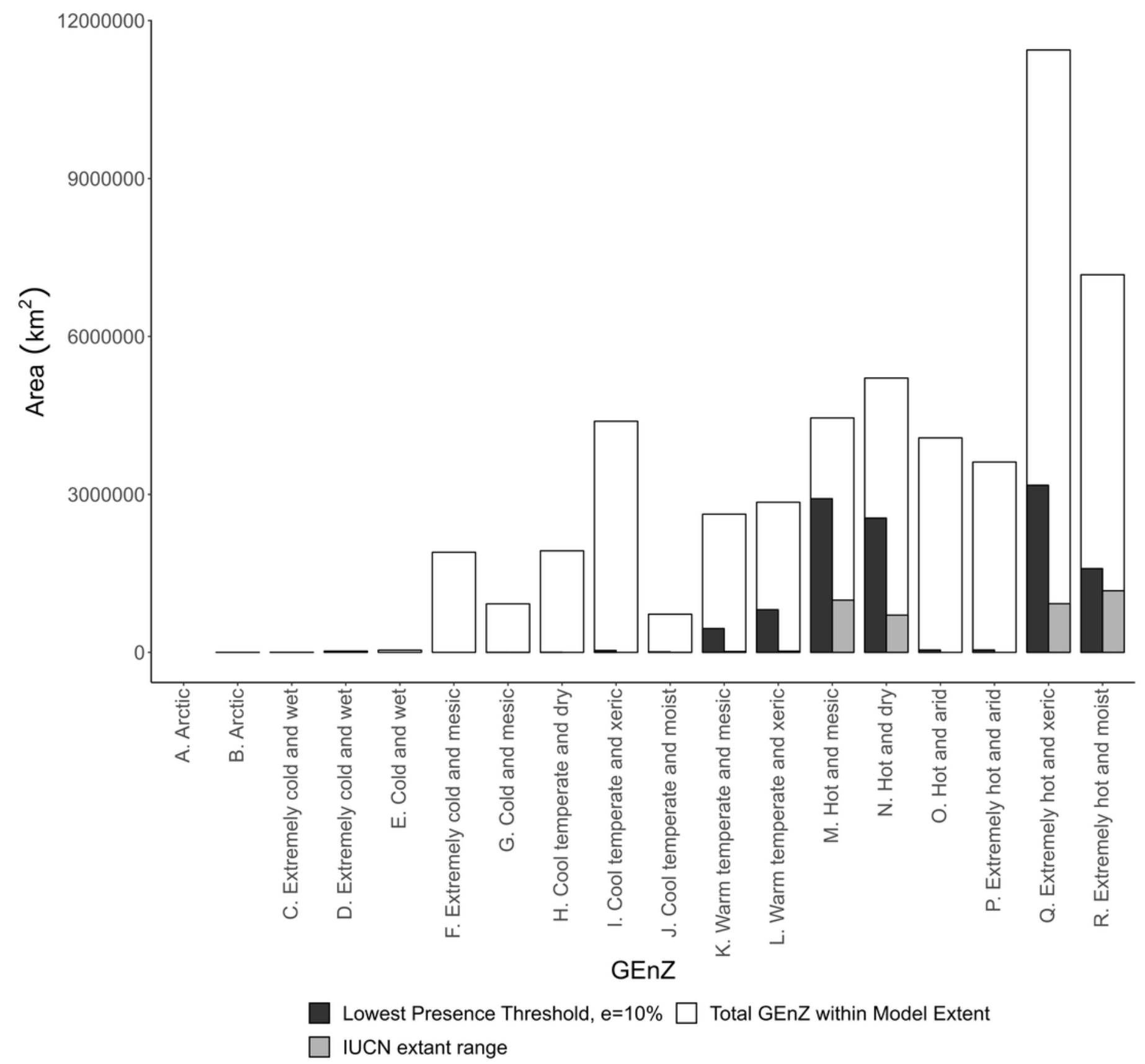


Figure 5

The percentage of Global Environmental Strata occupied by the modelled distribution of the lion.

The percentage of Global Environmental Strata occupied by the modelled lion distribution within the modelling extent of Africa, the Near East, and the Indian Subcontinent. This was used to inform maps of favourable Global Environmental Strata for the lion (figure 4).

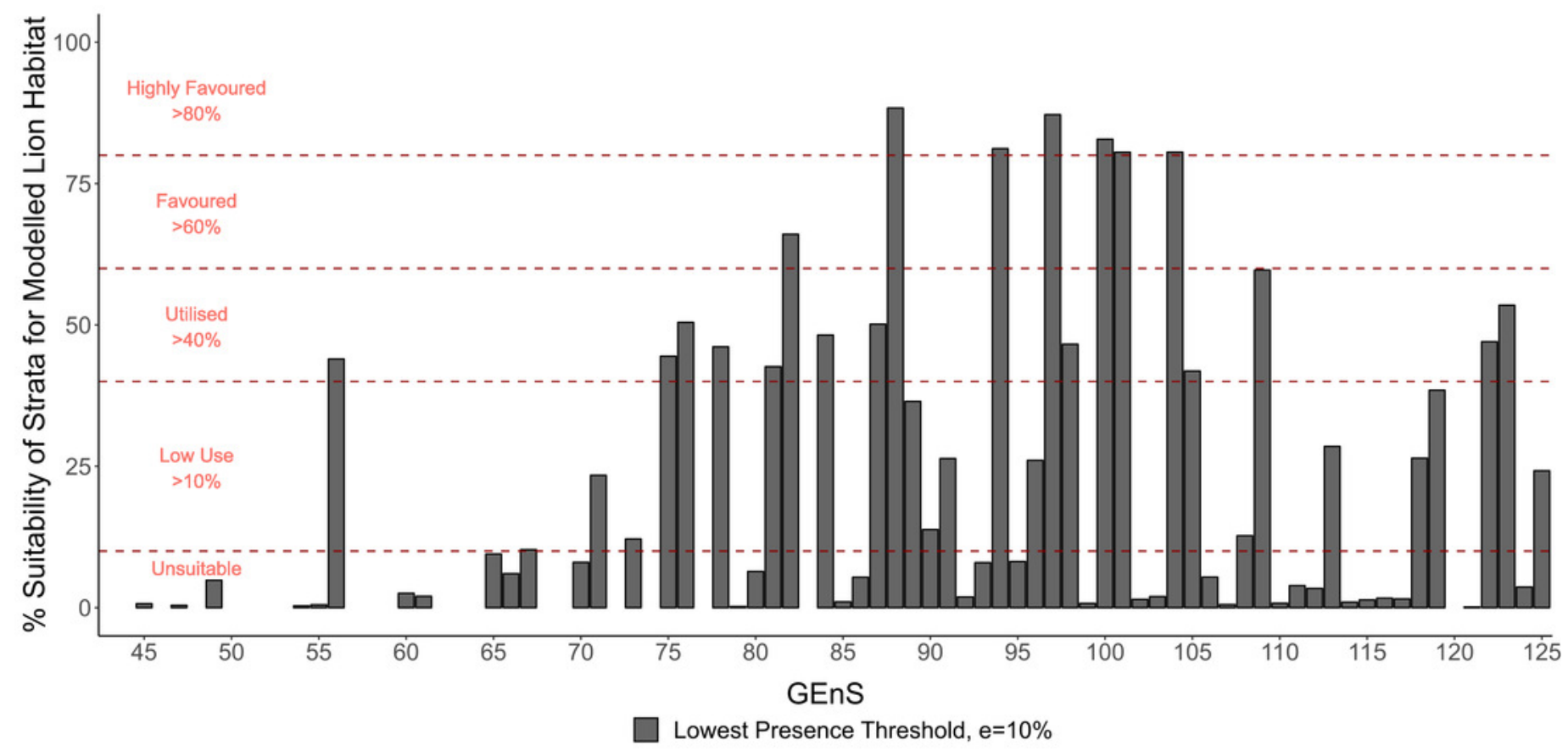




\section{Figure 6}

Modelled lion habitat suitability for the present-day, mid-Holocene and Last Glacial Maximum.

Modelled lion habitat suitability for the present-day, mid-Holocene and Last Glacial Maximum, based on global environmental strata (GEnS). Mid-Holocene and Last Glacial Maximum maps represent the combined suitability based upon nine and three coupled general circulation models respectively. We include an area of uncertainty surrounding the mid-Holocene greening of the Sahara and Arabia (Hoelzmann et al., 1998; Larrasoaña, Roberts, \& Rohling, 2013) and evidence of Lions and other savanna megafauna at (a) Tassili n'Ajer, (b) Wadi elObeid and (c) Aïr (Galvin, 2018) (see Appendix S5 for records). 

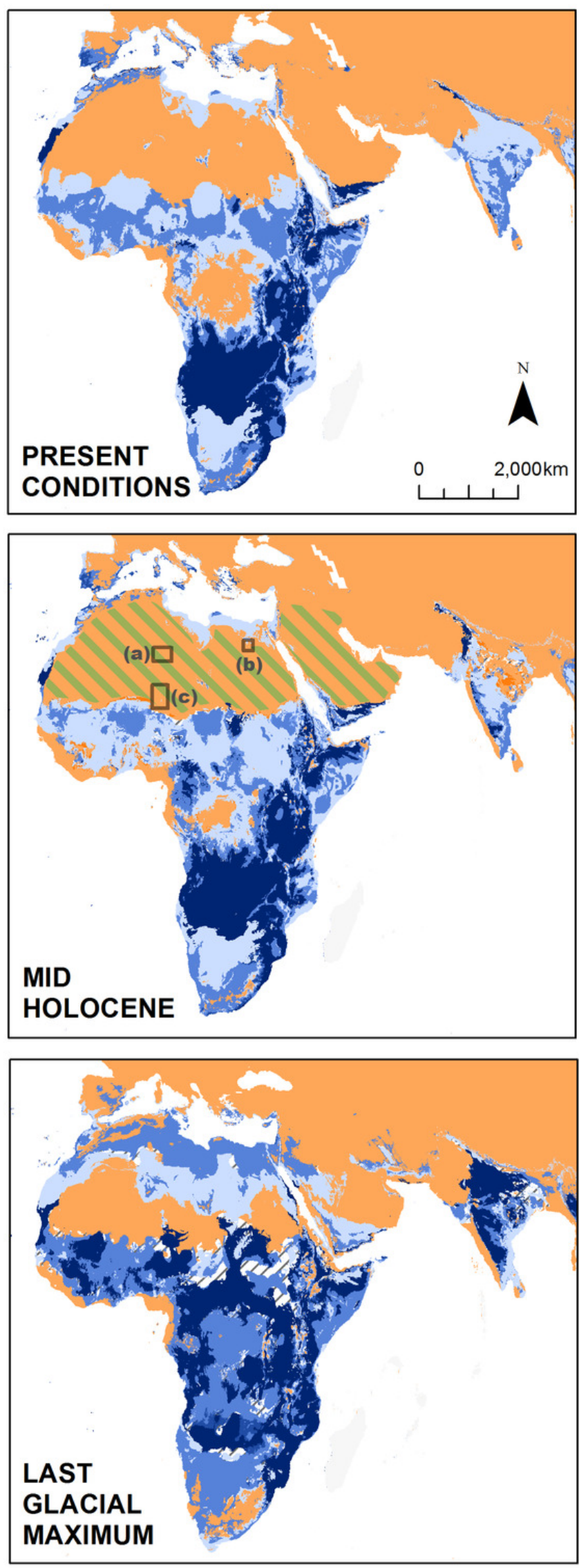

\begin{tabular}{l} 
Habitat Suitability \\
\hline Highly Favoured \\
Highly Favoured/Favoured \\
Favoured \\
Favoured/Utilised \\
Utilised \\
Utilised/Low Use \\
Low Use \\
Low use/Unsuitable \\
Unsuitable \\
U///, Model Uncertainty \\
Green Sahara Uncertainty
\end{tabular}




\section{Figure 7}

Changing area of favourable climatic conditions for the lion

The changing area of favourable climatic conditions for the lion is shown for the present-day, the mid-Holocene and the Last Glacial Maximum within Africa, the Near East and the Indian Subcontinent. Where model uncertainty exists between underlying mid-Holocene projections, we collapsed the classes "highly favoured/favoured", "favoured/utilised", "low use/utilised" and "unsuitable/utilised" into "highly favoured", "favoured", "utilised" and "low use" respectively. Utilised, favoured and highly favoured strata are more prevalent during the Last Glacial Maximum (39.8\% of total area) than for either the Mid-Holocene $(24.2 \%$ ) or presentday $(26.2 \%)$, which are characterised by greater areas of unsuitable and low use strata. The total area for the LGM is greater than the present-day and mid-Holocene due to lower sea levels at this time. 


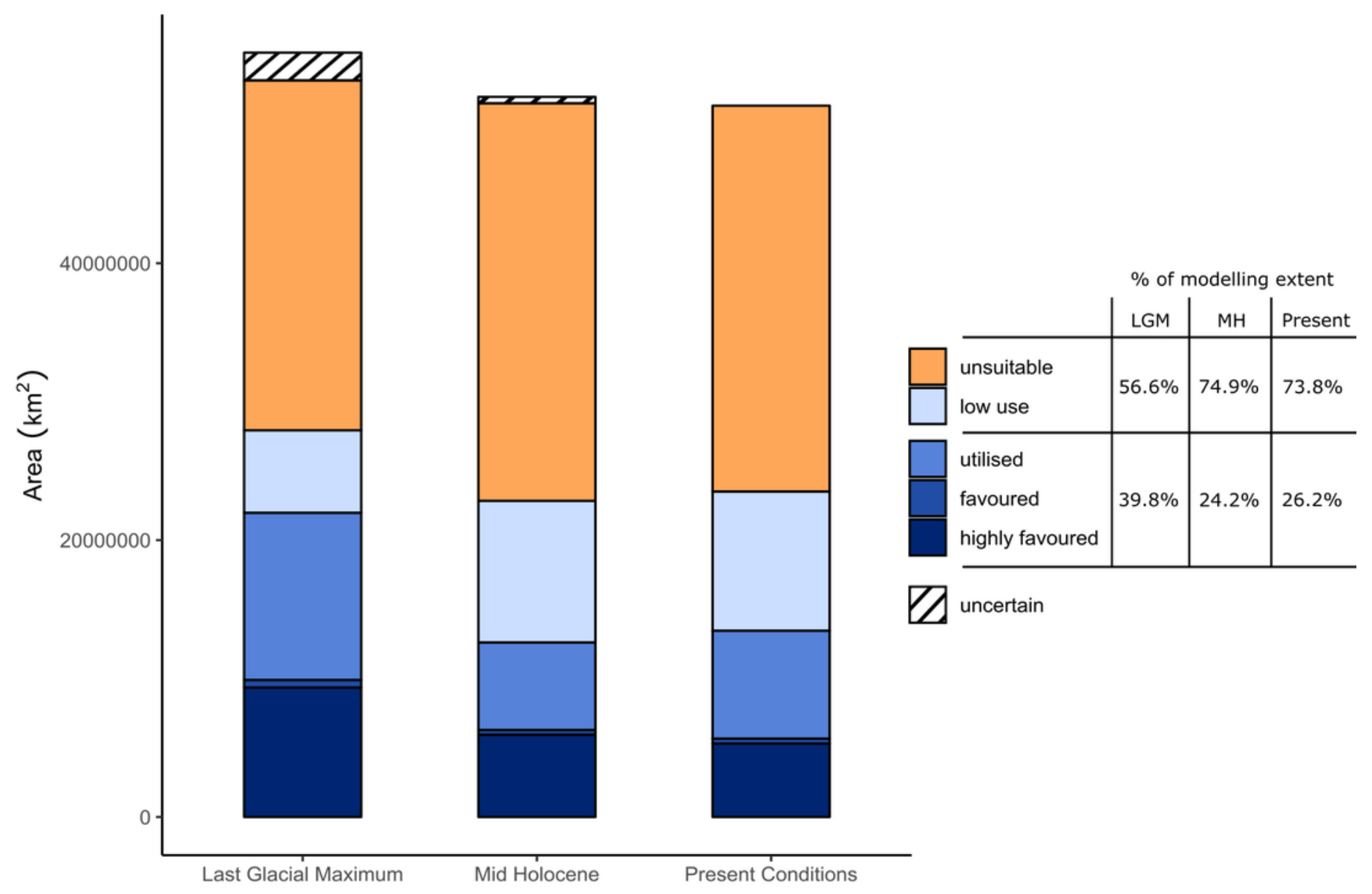




\section{Figure 8}

Global Environmental Strata through the Holocene within the Congo Basin

We display Global Environmental Strata (GEnS) for key areas across present, mid-Holocene and Last Glacial Maximum conditions within the Congo Basin (a). Strata colours are grouped into shades corresponding to Global Environmental Zone (b). Total area of each Global Environmental Zone within the modelling extent, and the suitability of each zone for the lion based upon our models, and on current lion range determined by the IUCN are displayed (b). The colours of each strata (a) are matched to the associated bar chart of Global Environmental Strata (c), which displays the suitability of each strata for the lion based upon the MaxEnt ecological niche model. 


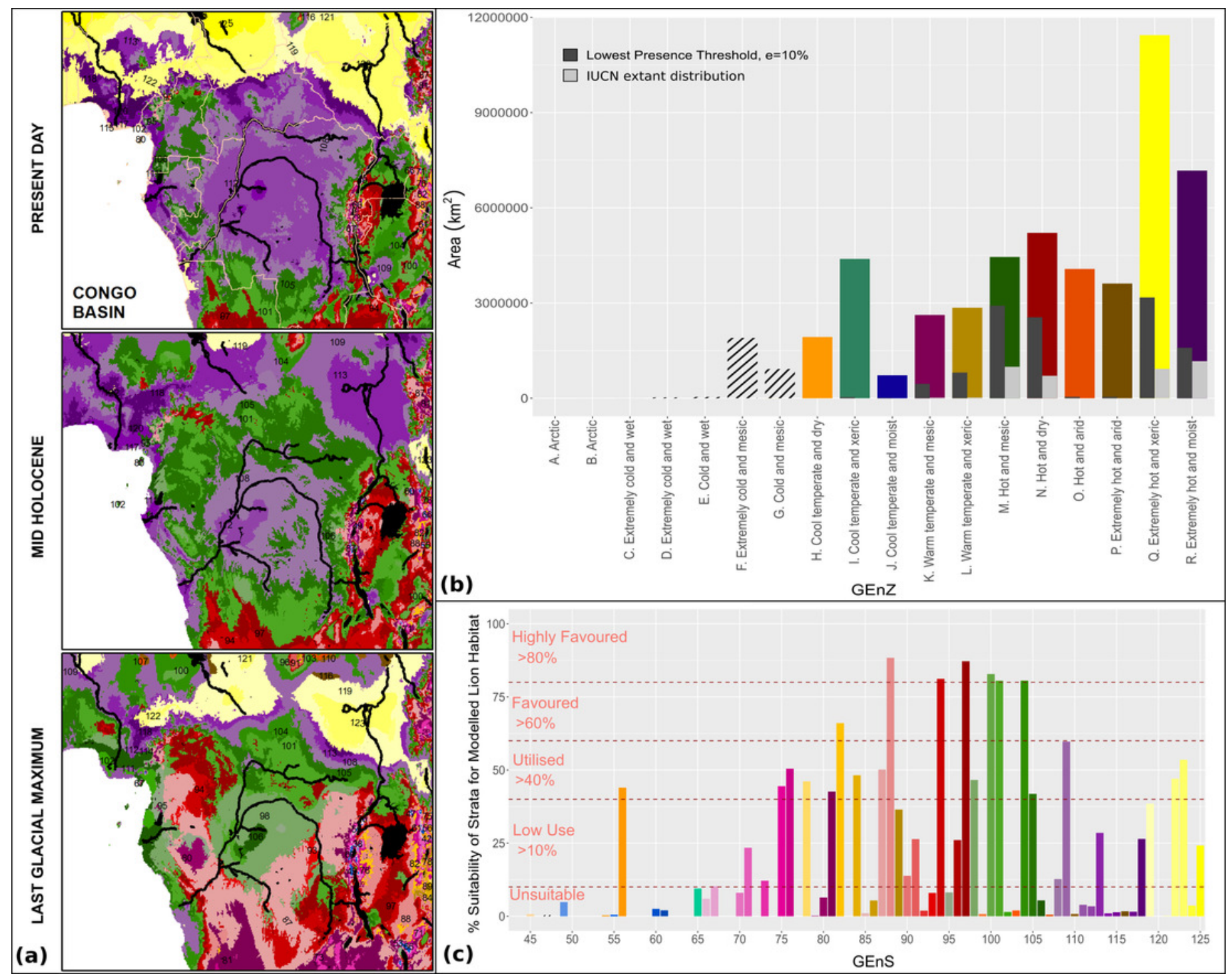




\section{Figure 9}

Global Environmental Strata through the Holocene within the Sahara

We display Global Environmental Strata (GEnS) for key areas across present, mid-Holocene and Last Glacial Maximum conditions within the Sahara (a). Strata colours are grouped into shades corresponding to Global Environmental Zone (b). Total area of each Global Environmental Zone within the modelling extent, and the suitability of each zone for the lion based upon our models, and on current lion range determined by the IUCN are displayed (b). The colours of each strata (a) are matched to the associated bar chart of Global Environmental Strata (c), which displays the suitability of each strata for the lion based upon the MaxEnt ecological niche model. 


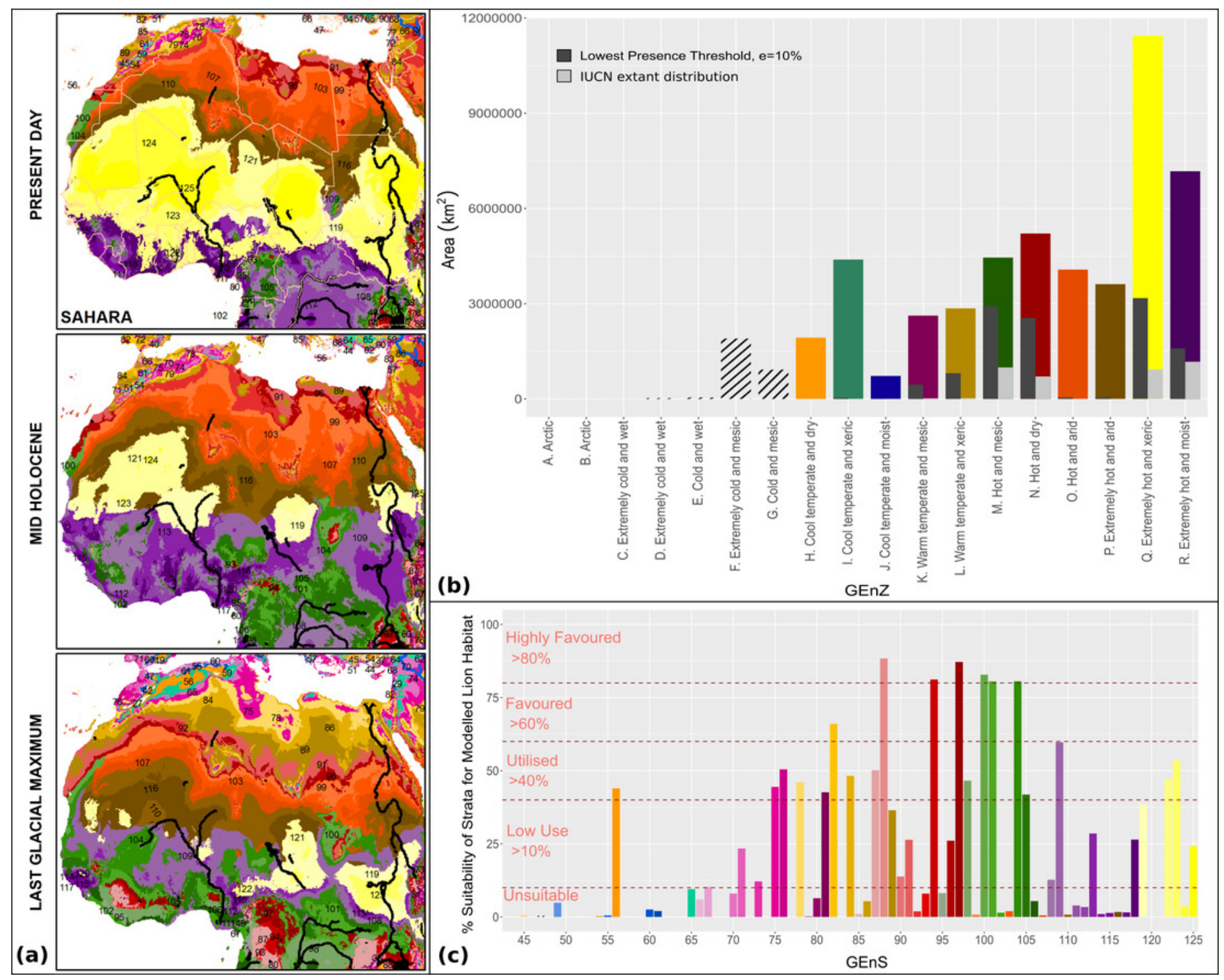




\section{Figure 10}

Global Environmental Strata through the Holocene within the Near East

We display Global Environmental Strata (GEnS) for key areas across present, mid-Holocene and Last Glacial Maximum conditions within the Near East (a). Strata colours are grouped into shades corresponding to Global Environmental Zone (b). Total area of each Global Environmental Zone within the modelling extent, and the suitability of each zone for the lion based upon our models, and on current lion range determined by the IUCN are displayed (b). The colours of each strata (a) are matched to the associated bar chart of Global Environmental Strata (c), which displays the suitability of each strata for the lion based upon the MaxEnt ecological niche model. 


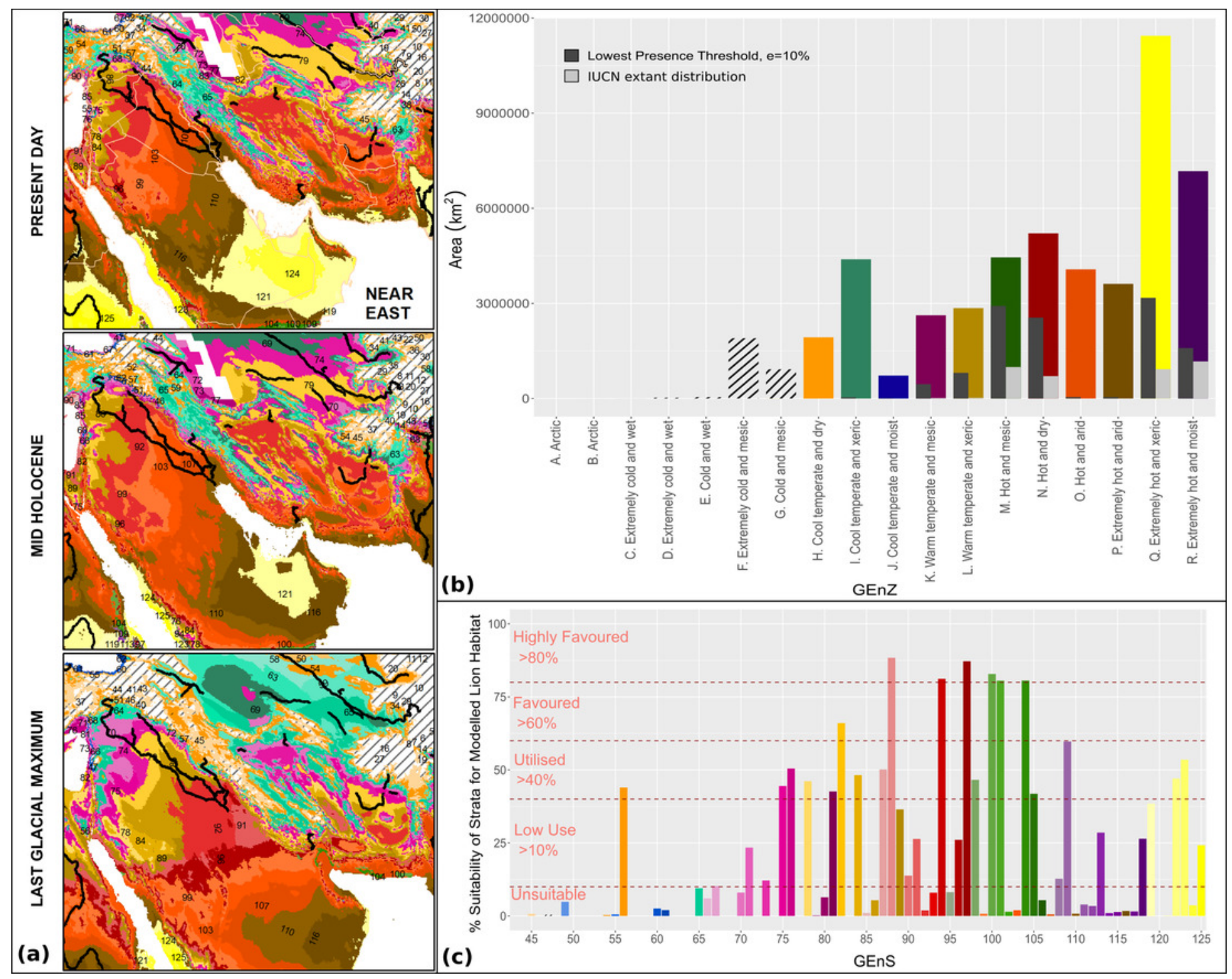




\section{Figure 11}

Global Environmental Strata through the Holocene within East Africa

We display Global Environmental Strata (GEnS) for key areas across present, mid-Holocene and Last Glacial Maximum conditions within East Africa (a). Strata colours are grouped into shades corresponding to Global Environmental Zone (b). Total area of each Global Environmental Zone within the modelling extent, and the suitability of each zone for the lion based upon our models, and on current lion range determined by the IUCN are displayed (b). The colours of each strata (a) are matched to the associated bar chart of Global Environmental Strata (c), which displays the suitability of each strata for the lion based upon the MaxEnt ecological niche model. 


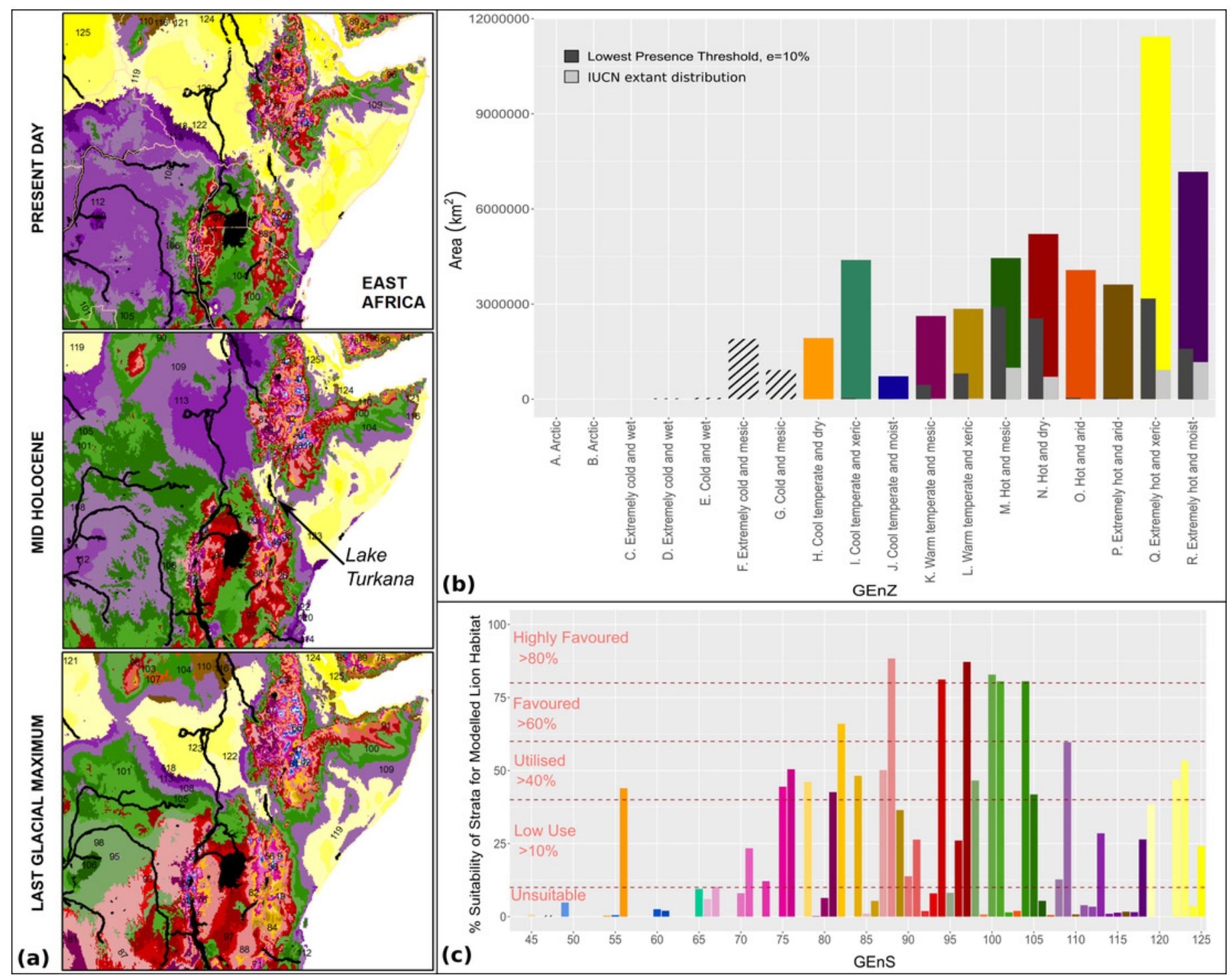

